\title{
Going Beyond STS Education: Building a Curriculum for Sociopolitical Activism
}

\author{
Derek Hodson
}

Accepted: 27 August 2020 / Published online: 8 January 2021

(C) The Author(s) 2021

\begin{abstract}
The focus of this paper is on the Science-Technology-Society (STS) initiative, developed in the 1980s, subsequently expanded to STSE to acknowledge environmental concerns and later expanded further to include the provision of opportunities for students to confront socioscientific issues (SSI), often of a controversial and certainly of a topical nature.

The article focuses on the key issues that need to be addressed in building such a curriculum, including selection of appropriate SSI, ensuring access to the necessary scientific knowledge, developing the necessary media literacy to access other material relevant to the issues, fostering the political awareness needed for critical interpretation of issues and building the ethical understanding needed to address the complex issues raised by controversial SSI. Teachers introducing SSI into the curriculum need to be sensitive to the profound emotions that can be generated among students encountering controversial issues for the first time. An understanding of emotional intelligence, emotional literacy and emotional competence is essential, and building students' capacities in these matters is crucial to helping them deal with potentially stressful and disconcerting learning situations that will inevitably arise.

I argue that a curriculum to build students' capacity for sociopolitical action on SSI can be developed through a 4-stage model: (1) appreciating the societal and environmental impact of scientific and technological change, and recognizing that science and technology are, to some extent, culturally determined; (2) recognizing that decisions about scientific and technological development are taken in pursuit of particular interests, that benefits accruing to some may be at the expense of others and that developments in science and technology are inextricably linked with the distribution of wealth and power; (3) addressing controversy, clarifying values, resolving ethical dilemmas, formulating and developing one's own views and justifying them through discussion and argument; and (4) preparing for and taking action on socioscientific and environmental issues. Stage 4 is further divided into learning about action, learning through action and learning from action. Learning about action focuses on learning the skills and strategies of sociopolitical action through movies, biographies and autobiographies, case studies and simulations, role-play and dramatic reconstructions. Learning through action comprises direct involvement in action-oriented projects outside the classroom that are likely to have tangible outcomes and consequences.
\end{abstract}

D. Hodson $(\bowtie)$

Science Education, Ontario Institute for Studies in Education, University of Toronto, 252 Bloor Street West, Toronto, ON M5S 1V6, Canada

e-mail: d.hodson@auckland.ac.nz 
The prime purpose of this action-oriented approach to addressing complex and controversial SSI is to enable young citizens to look critically at the society we have and the values that sustain it, and to ask what can and should be changed in order to achieve a more socially just democracy and bring about more environmentally sustainable lifestyles. It almost goes without saying that teachers who introduce SSI into the curriculum need to be sensitive to the need to assist students in dealing with potentially stressful and disconcerting learning situations. It is here that notions of emotional intelligence, emotional literacy and emotional competence can be helpful. Furthermore, there are many reasons why the translation of this kind of curriculum rhetoric into practical action in real classrooms will be extraordinarily complex and difficult. Such a radical change in the nature of the school curriculum puts a whole raft of new demands on teachers; it challenges many of the assumptions on which schooling is traditionally based; it is predicated on a commitment to bringing about extensive and wide-ranging social change at local, regional, national and international levels.

Résumé Cet article porte sur l'initiative science, technologie et société (STS) mise sur pied dans les années 1980, ensuite devenue STSE afin de reconnaître les préoccupations environnementales, et qui s'est élargie encore davantage plus tard pour inclure la possibilité pour les étudiants d'aborder des questions socioscientifiques (SSI), souvent de nature controversée et assurément d'actualité.

Cet article relève les questions clés qui doivent être abordées au moment d'élaborer un tel programme d'étude, y compris le choix de questions socioscientifiques appropriées, l'assurance d'un accès aux connaissances scientifiques nécessaires, le développement de la culture médiatique nécessaire pour accéder à d'autres matériels pertinents aux problèmes, le développement de la prise de conscience politique nécessaire pour l'interprétation critique des problèmes et la construction de la compréhension éthique nécessaire pour aborder les questions complexes soulevées par les questions socioscientifiques controversées. Les enseignants qui intègrent les questions socioscientifiques au programme doivent être sensibles aux émotions profondes qui peuvent être suscitées chez les élèves confrontés pour la première fois à des questions controversées. Une compréhension de l'intelligence émotionnelle, de la littératie émotionnelle et des compétences émotionnelles est essentielle. De plus, le renforcement des capacités des élèves à cet égard est primordial pour les aider à faire face aux situations d'apprentissage potentiellement stressantes et déconcertantes qui se présenteront inévitablement.

Je soutiens qu'un programme d'étude visant à renforcer la capacité des étudiants en matière d'action sociopolitique sur les questions socioscientifiques peut être élaboré suivant un modèle en quatre étapes : (1) l'appréciation de l'impact sociétal et environnemental du changement scientifique et technologique, assorti de la reconnaissance que la science et la technologie sont, jusqu'à un certain point, déterminées culturellement ; (2) la reconnaissance du fait que les décisions relatives au développement scientifique et technologique sont prises pour servir des intérêts particuliers, que les avantages revenant à certains peuvent être au détriment des autres et que les progrès de la science et de la technologie sont inextricablement liés à la répartition des richesses et du pouvoir ; (3) la discussion sur la controverse, la clarification des valeurs, la résolution des dilemmes éthiques, la formulation et l'élaboration de ses propres points de vue et leur justification par la discussion et l'argumentation ; et (4) la préparation et l'action sur les questions socioscientifiques et environnementales. L'étape 4 se divise à nouveau en apprentissage sur l'action, apprentissage par l'action et apprentissage de l'action. L'apprentissage sur l'action porte sur l'apprentissage des compétences et des stratégies de l'action sociopolitique à travers des films, des biographies et des autobiographies, des études de cas et des simulations, des jeux de rôle et des reconstitutions théâtrales. L'apprentissage par l'action comprend la participation directe à des projets orientés vers l'action en dehors de la salle de classe qui sont susceptibles d'avoir des résultats et des conséquences tangibles.

L'objectif principal de cette approche orientée vers l'action pour aborder les questions socioscientifiques complexes et controversées est de permettre aux jeunes citoyens de porter un regard critique sur la société que nous avons et sur les valeurs qui la sous-tendent, et de se demander ce qui peut et doit être changé afin de parvenir à une démocratie plus juste socialement et instaurer des modes de vie plus durables sur le plan 
environnemental. Il va presque sans dire que les enseignants qui intègrent les questions socioscientifiques au programme d'étude doivent être sensibles à la nécessité d'aider les élèves à faire face à des situations d'apprentissage potentiellement stressantes et déconcertantes. C'est ici que les notions d'intelligence émotionnelle, de littératie émotionnelle et de compétence émotionnelle peuvent être utiles.

En outre, il existe de nombreuses raisons pour lesquelles la traduction de ce type de discours sur les programmes scolaires en actions pratiques dans de vraies salles de classe sera extraordinairement complexe et difficile. Un changement aussi radical dans la nature du programme d'étude impose un ensemble de nouvelles exigences aux enseignants; il remet en question bon nombre des hypothèses sur lesquelles la scolarisation est traditionnellement fondée; il repose sur un engagement à apporter des changements sociaux profonds et de grande envergure aux niveaux local, régional, national et international.

Keywords Socioscientific Issues $\cdot$ Controversy $\cdot$ Equity $\cdot$ Politicization $\cdot$ Action-Oriented

I want you to act as if the house is on fire, because it is.

- Greta Thunberg

\section{Introduction}

Towards the end of October 2018, when Doug McDougall emailed to say, "We want to celebrate the $20^{\text {th }}$ year of publication (of CJSMTE) by soliciting articles or commentaries from the editors-in-chief, founding editors and long-term contributors to the journal", I was delighted that the occasion would not go unmarked. Among the ideas and topics Doug suggested, the one that caught my eye was "A look at the future in your discipline and where we might go in the next five, 10 or 20 years". While we can be certain that the science curriculum will change over the next 20 years, only someone very foolhardy would predict exactly how it would change. Consequently, my preference is to present a case for the ways in which I believe the science curriculum should change.

When considering the science curriculum, there is great value in distinguishing among four major categories of learning goals:

- Learning science - acquiring a sound understanding of some fundamental concepts, ideas, principles and theories of science and the capacity to use them appropriately and effectively in both real-world and simulated situations.

- Learning about science and scientific practice - developing an understanding of the characteristics of scientific inquiry, the role and status of the knowledge it generates, the social and intellectual circumstances surrounding the origin and development of important scientific theories, the ways in which the scientific community establishes and monitors professional practice, including clear understanding of the linguistic conventions for reporting, defending, scrutinizing and validating scientific claims, and awareness of the complex interactions among science, technology, society and environment.

- Doing science - engaging in and developing expertise in designing and conducting scientific inquiries, problem-solving, modelling and theory-building, and communicating findings and conclusions to others.

- Addressing socioscientific issues (SSI) - developing the critical skills to confront the scientific, personal, social, economic, environmental and moral-ethical aspects of SSI, and finding effective, appropriate and socially responsible ways to respond. 
An article focused on the first goal might consider a range of issues: the need for new content knowledge (especially in the biological and medical sciences); the need to find ways to respond more appropriately to individual differences among students in knowledge, skills, attitudes, aspirations, values and cultural traditions; the contextualization of science content in ways and situations that are more appealing to more students; the more productive utilization of contemporary IT and computer technology in designing effective learning methods. For item two, attention might be directed towards a critique of the so-called consensus view of the nature of science (NOS) promoted by Lederman et al. (2002), Abd-El-Khalick (2012) and others - in particular, its failure to reflect contemporary scientific practice and the views of scientists, the overly simplified, sometimes confused, frequently misleading, often unhelpful and philosophically naive nature of some of the individual items that comprise it.

Time is well overdue for replacing this very influential view with one that encompasses, at the very least, the characteristics of scientific inquiry (including its sub-disciplinary variants), the role and status of the scientific knowledge it generates, the modelling that attends the construction of scientific theories, the social and intellectual circumstances of their development, how scientists work as a social group, the linguistic conventions for reporting, scrutinizing and validating knowledge claims, and the ways in which science impacts and is impacted by the social context in which it is located. Regarding item 3, authors might advocate much greater opportunities for students to gain more experience of planning, conducting and reporting their own scientific investigations using the kind of equipment currently in use in modern laboratories rather than the often outdated and frequently poorly maintained equipment in school laboratories, experience working alongside and in collaboration with practising scientists, conducting fieldwork using up-to-the-minute technological support (including drones) and participating in citizen science projects.

Despite the attractions of addressing such matters, I have chosen to consider item four in the list. During the 1980s, the Science-Technology-Society (STS) initiative - particularly through the influential work of Glen Aikenhead and Joan Solomon - sought to effect a substantial shift of emphasis in science education by encouraging students to use their everyday experiences to understand important features of their social environment (the society component), the artificially constructed environment (the technology component) and the natural environment (the science component). In effect, the goal of STS education (later expanded to STSE to acknowledge environmental concerns) was seen as utilizing students' real-world experiences and awareness of issues as a context for improved learning of science.

A convincing case for providing students with opportunities to confront socioscientific issues (SSI) in the science and technology curriculum can be made on grounds that it motivates students, personalizes learning, enhances the learning of science content, contextualizes nature of science understanding and engages students in problem-based situations that assist the development of higher-order thinking skills. Alternatively, one can argue that no justification is required beyond acknowledgement that one of the principal goals of science education is the achievement of what Shen (1975) calls civic scientific literacy - that is, the knowledge, skills, attitudes and values to deal with everyday issues that have a science and/or technology dimension and, in adult life, to play an active part in decision-making and policy setting.

Ratcliffe and Grace (2003) have identified a number of key features of SSI. First, they have a basis in science, frequently at the frontiers of scientific knowledge, where data and evidence may be incomplete, conflicting or confusing. Second, they involve the formation of opinions and making of choices at a personal and societal level. In addition, they address local, national and/or global issues, with attendant political and societal implications; they involve some cost-benefit analysis in which probability and risk interact with values; and they often feature prominently in the media. Zeidler et al. (2005) contrast what they term "SSI-oriented teaching" with STS or STSE education in terms of its emphasis on developing habits of mind (specifically, developing skepticism, maintaining open-mindedness, acquiring the capacity for critical thinking, recognizing that there are multiple forms of inquiry, accepting ambiguity and searching for datadriven knowledge) and "empowering students to consider how science-based issues reflect, in part, moral principles and elements of virtue that encompass their own lives, as well as the physical and social world 
around them" (p. 357). They argue that, while STS education emphasizes the impact of scientific and technological development on society, it does not focus explicitly on the moral-ethical issues embedded in decision-making: "STS(E) education as currently practiced... only 'points out' ethical dilemmas or controversies, but does not necessarily exploit the inherent pedagogical power of discourse, reasoned argumentation, explicit NOS considerations, emotive, developmental, cultural or epistemological connections within the issues themselves... nor does it consider the moral or character development of students" (p. 359). In consequence, they say, STS education has become marginalized. Similar arguments can be found in Zeidler and Sadler (2008a, b) and Zeidler et al. (2009).

A quarter century ago, Bingle and Gaskell (1994) noted that STS education tends to emphasize what Latour (1987) calls "ready-made science" (with all its attendant implicit messages about certainty) rather than "science-in-the-making" (with its emphasis on social construction). Interestingly, Simmons and Zeidler (2003) argue that it is the priority given to science-in-the-making through consideration of controversial SSI that gives the SSI approach its special character: "Using controversial socioscientific issues as a foundation for individual consideration and group interaction provides an environment where students can and will develop their critical thinking and moral reasoning" (p. 83, emphasis added). In a further attempt at delineation, Zeidler et al. (2002) claim that the SSI approach has a much broader scope, in that it "subsumes all that STS has to offer, while also considering the ethical dimensions of science, the moral reasoning of the child, and the emotional development of the student" (p. 344). It is also important to consider the myriad ways in which the concerns and priorities of the SSI-oriented approach overlap with those of many other movements and initiatives - principally, science education for citizenship, science education for public understanding, public awareness or public participation, education for sustainability, multicultural and antiracist science education, global education and peace studies.

It is not my intention to become embroiled in a "turf war" or to engage in evaluation of claims by rival camps that ought to be fighting the same battle. My view is that neither STSE nor SSI-oriented teaching goes far enough. For my taste, both are too conservative. My inclination is towards a much more radical, politicized form of science and technology education in which students not only address complex and often controversial environmental and socioscientific issues (SSI) and formulate their own position concerning them but also prepare for, and engage in, sociopolitical actions that they believe will "make a difference", asking critical questions about how research priorities in science are determined, who has access to science, how science could (and perhaps should) be conducted differently, how scientific and technological knowledge are deployed, whose voices are heard, whose reading of a situation or interpretation of an issue are considered in formulating policy, and how action can be taken at individual, group and community level to influence policy and practice.

This article addresses some of the issues relating to the establishment of this approach to science education. It looks at ways of enabling young people to be part of the solution to society's problems rather than contributing to them. It can be summed up as a plea for (i) assisting and supporting students in understanding complex issues, including exploration of the complex sociopolitical context in which the problem/issue is located; (ii) resolving conflicts of interest, considering any moral-ethical dimensions the issue raises and establishing a personal view; and (iii) building a commitment to taking appropriate sociopolitical action, both individually and collectively.

What makes this kind of curriculum unique is its commitment to student action. The simple point is that it is almost always much easier to proclaim that one cares about an issue than to do something about it, and to do it consistently, coherently and effectively. An action-oriented curriculum is predicated on the premise that our opinions and values are worth very little until we live them. Rhetoric and espoused values will not bring about a reappraisal of policy, establish social justice with respect to SSI or halt environmental degradation. Not only must we change our behaviour, we must also take action to change the behaviour of others and ensure that alternative voices and their underlying interests and values are brought to bear on policy decisions. 
Building such a curriculum has four key elements. First, learning about the issues - that is, focusing on the science and technology aspects of important SSI, recognizing the social, cultural and economic contexts in which they are located, developing the nature of science knowledge that builds robust understanding of contemporary scientific practice, and acquiring the media literacy necessary to access and read with critical understanding a wide variety of information sources. Second, learning to care about issues and the people impacted by them, including a focus on dealing with controversy, addressing values and developing concern for the views, needs and interests of others. Third, engaging and managing the powerful emotions often generated by SSI. Fourth, learning about sociopolitical action, taking action and evaluating action.

Because the changes we need to effect encompass changes in lifestyle that will be quite profound and potentially disconcerting for many people in industrialized societies and will inevitably run counter to the goals, aspirations and desires instilled in us by the popular media, current consumerist rhetoric and the world of advertising, it is not just school-based education that we need to reform. We need to establish a new climate of concern and commitment throughout education at all levels and we need to involve a much wider range of educational venues, including parks and gardens, nature centres, museums, zoos and aquaria, science centres and environmental clubs. We need to revitalize education in the home, in the workplace, in community centres and through advertising and public notices. We need to mobilize effective education through leisure activities: through the print and broadcast media, the Internet and social networking media; through movies, theatre, literature, music and dance; and through examples set by prominent members of the community.

Unprecedented levels of cooperation, support and collaboration will be necessary among national and local governments, government agencies and public services, research establishments, environmental groups, formal and informal educational institutions, the business and industrial sector, trade unions, cultural and community organizations, youth groups, voluntary organizations, schools and families. Through all these outlets, we need to focus very directly on how we live and how we should live in the future if we really want to establish and maintain a more equitable and socially just society and an environmentally sustainable lifestyle.

Our current educational priorities are hopelessly misplaced, inadequate for the task of preparing students for responsible and active citizenship. There is, for example, way too much emphasis on preparing students for later study of science or subsequent employment as scientists, way too much emphasis on competition, way too much emphasis on prespecified and highly detailed (but often essentially trivial) learning outcomes, way too much emphasis on rigorous and systematic testing for so-called educational standards and way too much teacher-centred pedagogy. As a result, students are led to distrust and devalue their own knowledge, skills, values and experiences. In consequence, they look to experts as the source of all views, solutions to problems and decisions on SSI. Instead, we need a curriculum that promotes problem-solving, especially real-world, complex and ill-defined problems, not one focused on the steady accumulation of knowledge. We need a curriculum that fosters critique and intellectual independence rather than conformity and compliance, yet also promotes the cultivation of interdependence and potential for community building. We need a curriculum that (i) equips students to make judgments and reach decisions on complex SSI; (ii) develops the capacity to deal with change, uncertainty and unpredictability; (iii) cultivates the ability to ascertain what is desirable/undesirable and what is possible in the long and short terms; (iv) pays much more attention than has been usual to values issues and the active promotion of democracy and social justice; and (v) prepares students for taking direct and indirect action in pursuit of changes they consider desirable.

Of course, if students are to take effective action, it is essential that they gain robust knowledge of the social, legal and political system(s) that prevail in the communities in which they live and develop a clear understanding of how decisions are made within local, regional and national government, and within industry, commerce and the military. Without knowledge of where and with whom power of decisionmaking is located and awareness of the mechanisms by which decisions are reached, intervention is not possible. Thus, the curriculum advocated in this article would require a concurrent programme designed to achieve a measure of political literacy, including knowledge of how to engage in collective action with 
individuals who have different competencies, backgrounds and attitudes, but share a common interest in a particular SSI. Such shifts of curricular emphasis would necessarily trigger a shift in pedagogy in the direction of greater learner autonomy, more extensive and imaginative utilization of the resources of industry and commerce, and increased involvement in a group work.

\section{Building a Curriculum}

The first step in building an issues-based, action-oriented curriculum is the selection of appropriate SSI and their organization into a coherent and theoretically justifiable programme. What should be the criteria for selection? Should it be student interest, perceived importance in contemporary society, cutting-edge science and technology or lively and public controversy? Should priority be given to the ready availability of curriculum resources or conversely to the lack of readily available material because that would require students to search for further knowledge and information (an important learning goal in itself)? Since all these criteria have a legitimate claim, the ideal may be a judicious mix of local, regional/national and global issues of significance, together with a range of SSI chosen by the students from among personal interests.

It seems self-evident that the most effective way of learning to confront SSI is by confronting SSI, provided there are appropriate levels of guidance, criticism and support from an experienced teacher. What I have in mind is a three-phase approach involving modelling (the teacher demonstrates and explains an appropriate approach to addressing SSI), guided practice (students perform specified tasks with help, criticism and support from the teacher) and application (students perform independently of the teacher, either individually or in groups). Teacher modelling (phase one) is predicated on the assumption that watching and questioning someone skilled in addressing SSI will facilitate the learning of successful investigative strategies. In the second phase (guided practice), teachers provide a carefully sequenced programme of investigations during which their role is to act as learning resource, facilitator, consultant, supporter and critic. The assumption is that students will become more expert in addressing SSI as a consequence of practice and experience, through evaluative feedback provided by the teacher and generated in inter-group criticism and discussion, and through intra-group reflection on the activity, both as it progresses and on completion. To be intellectually autonomous, however, students must eventually be able to manage without teacher assistance and take responsibility for planning, conducting and reporting their own inquiries (the application stage).

\section{Understanding the Science}

If students are to address SSI at any level beyond the merely superficial, they need relevant scientific knowledge. Simple common sense tells us that those who know more about the science underpinning a particular SSI will be better positioned to understand the problems, evaluate different positions, reach their own conclusions, make an informed decision on where they stand in relation to the issue and argue their point of view. Key curriculum questions concern the depth of knowledge required and the manner in which it should be acquired. It seems almost trite to state that the level of scientific knowledge needed is that which is sufficient to enable students to understand the nature of the problem and what might constitute appropriate evidence on which to base their decision-making, and that this level will vary substantially from issue to issue. Whether that scientific knowledge should be acquired through prior instruction or as the need arises is best decided on an issue-by-issue basis. As is so often the case in education, there is no universal answer; different situations demand different approaches and different SSI create widely different knowledge needs.

Much depends on whether the entire curriculum is given over to an SSI-oriented approach or SSI are included as occasional add-ons to an otherwise content-oriented curriculum, and on whether that particular science content is likely to be taught and utilized elsewhere in the curriculum. Sometimes, specialized 
knowledge well beyond science is needed. For example, in order to address the "septic tank crisis" in their school, students in Pedretti's (1997) study needed technical knowledge about septic tank systems, waste management practices, filtration methods, environmental hazards and local government regulations (clearly, not the usual content of school science courses). Similarly, those seeking to assess likely health risks from overhead power lines, nuclear power stations or the dumping of toxic waste will need considerable relevant technological knowledge. Trying to ascertain ahead of time exactly what technological knowledge will be required for addressing a range of SSI is virtually impossible, especially if topical issues are studied at short notice. Providing such knowledge as the need arises is the only practical approach.

Of course, it is impossible to equip students with thorough first-hand knowledge of all the science underlying every important SSI. Moreover, given the pace of scientific and technological development it is likely that some of the scientific knowledge students will need if they are to make informed decisions on important SSI they encounter in later life may, as yet, be undiscovered. However, we do know what knowledge, skills and attitudes are essential for appraising scientific reports and evaluating scientific arguments - in particular, an understanding of the status of particular scientific knowledge, the ways in which it is generated, communicated and scrutinized by the community of scientists, and the extent to which it can be relied upon to inform critical decisions about SSI. Students need to know what constitutes a welldesigned inquiry and a well-argued conclusion.

They need the capacity to interpret reports, make sense of disagreements, evaluate knowledge claims, scrutinize arguments, distinguish among facts, arguments and opinions, make judgements about good science, bad science and non-science, detect error, bias and vested interest and so on - all the things we have come to know as nature of science (NOS) understanding. Kolstø (2001) sums up the NOS knowledge and understanding needed for addressing SSI in terms of eight major elements: (i) distinguishing between science-in-the-making, where dispute, disagreement and uncertainty are to be expected, and ready-made science, on which we can rely; (ii) recognizing that sociocultural, political, economic and religious factors can impact on priorities for scientific research and development, and on the knowledge claims that are accepted; (iii) ability to evaluate the quality of scientific and statistical evidence, and to judge the appropriateness of anecdotal and experiential knowledge; (iv) ability to appraise the degree of support for a knowledge claim and the quality of the argument that establishes the warrant for belief; (v) having a sceptical approach, that is, a critical, questioning stance and a commitment to resist jumping to conclusions until suitable evidence and arguments have been assembled; (vi) awareness of the importance of contextual factors when evaluating knowledge claims, including the social status of the actors and their institutional allegiance; (vii) sensitivity to the underlying values, ideologies and potential for bias in the design and reporting of scientific investigations; and (viii) awareness of the constraints that might limit the application of generalized theoretical knowledge to particular real-world situations.

A simple checklist of questions can be enormously helpful for students reading reports of specific research studies: Who conducted the research and where was it conducted? How was the research funded? Was the research sponsored and, if so, by whom? What is being claimed? What evidence supports the claim? How was the evidence collected? How was the evidence interpreted? What assumptions are made and what theories are used in arguing from evidence to conclusion? Do the authors use well-established theory or do they challenge such theories? Are alternative interpretations and conclusions possible? What additional evidence would help to clarify or resolve issues? Have there been other studies conducted by these scientists or by others?

\section{Language Issues}

If students are to address SSI thoroughly and critically, they need a robust understanding of scientific language and how it is deployed in scientific communication and argumentation. Scientific communication can be categorized as follows: (i) communication among scientists via research journals and conference papers; (ii) popularization and dissemination of knowledge generated by the scientific community via 
newspapers, magazines, television and Internet websites; and (iii) formal education via textbooks and other curriculum materials. We need to ensure that students develop proficient and critical reading skills for all three types of text - that is, the ability to (i) determine when something is an observation, inference, hypothesis, conclusion or assumption; (ii) distinguish between an explanation and the evidence for it; and (iii) recognize when the author is asserting a claim to "scientific truth", expressing doubt or engaging in speculation.

Critical reading skills need to be modelled and taught, carefully and systematically. Specifically, students need advice, criticism and support in their efforts to connect items of information within and across texts, evaluate the validity and reliability of all information used, weigh the rival merits of alternatives, assess consistency and inconsistency and seek to resolve inconsistencies by gathering further information. They need to know the form, structure and language of scientific arguments, the kind of evidence invoked and how it is organized and deployed and the ways in which theory is used and the work of other scientists cited to strengthen the case.

The need to access information from a wide variety of sources (magazines, newspapers, TV and radio broadcasts, publications of special interest groups and the Internet) raises the important issue of media literacy. Students who are media literate are able to access, comprehend, analyze, evaluate, compare and contrast information from a variety of sources and utilize that information judiciously and appropriately to synthesize their own detailed summary of the topic or issue under consideration. They can recognize that the deployment of a particular language, symbols, images and sound in a multimedia presentation can each play a role in determining a message's impact and will have a profound influence on its perceived value and credibility. They are able to ascertain the writer's intentions, determine any sub-text and implicit meaning, detect bias and vested interest and distinguish between good, reliable information and poor, unreliable information. They are alert to the fact that those skilled in producing printed, graphic and spoken media use particular vocabulary, grammar, syntax, metaphor and referencing to capture our attention, trigger our emotions, persuade us of a point of view and, on occasions, by-pass our critical faculties altogether. They understand that material may be biased and may use a range of journalistic techniques such as emotive language, hyperbole and innuendo, provocative pictures and images, and emotionally manipulative background music, to persuade readers, viewers and listeners of a particular point of view. If students are to develop these capabilities, there needs to be a systematic programme of instruction, practice, support and criticism.

\section{Science as a Social Practice}

A key element in learning about science is recognition that science is a social practice in two distinct senses. First, it is located within a social, political and economic environment that has a major impact on practice and priorities. Second, it is governed, directed and monitored by decisions taken within the community of practitioners. In other words, the practice of science is profoundly influenced by social forces both externally and internally. With respect to external forces, it is important for students to recognize that science is not propelled solely by its own internal logic or by a simple search for the truth; rather, it is motivated and shaped by the needs, interests, motives, personal beliefs, values, aspirations and political attitudes of scientists, the views of individuals, groups and organizations willing and able to provide the necessary funding, and by public opinion. Necessarily, it reflects the history, power structure and political climate of the wider community in which it is embedded. Necessarily, it reflects the prevailing social, economic, political and moral-ethical attitudes and values of that community. In other words, science is in large part a product of its time and place. The words of Young (1987) provide a succinct summary of the situation:

There is no other science than the science that gets done. The science that exists is the record of the questions that it has occurred to scientists to ask, the proposals that get funded, the paths that get 
pursued... matters for a given society, its educational system, its patronage system and its funding bodies. (pp. 18 and 19)

Several important points follow. First, the body of scientific knowledge exists as a tradition, with a history, during which many different goals, attitudes and values will have left a mark. Second, to be admitted to the corpus of approved scientific knowledge, theories have to be socially, culturally and politically acceptable as well as scientifically justifiable. Third, we can and probably should bring different goals, attitudes and values to bear on future decision-making. Fourth, science is both culturally dependent and culturally transforming, arising directly from the problems we encounter, the needs and interests we develop and the questions we ask, and impacting very directly and profoundly on the social, cultural and economic fabric of society, including the language in which we express our thoughts and the ways in which we conduct our daily lives.

Turning to the internal social dimensions of science, we need to assist students in appreciating the internal norms, values and traditions that inform and direct scientific practice. As a set of rigorous and carefully monitored procedures, science embodies a number of values: orderliness, care and precision, meticulous and critical attentiveness, accuracy, reliability and replicability. The knowledge generated by scientists has to conform to certain values: clarity, coherence, universalism, stability, tentativeness and fecundity/fruitfulness (in the sense of solving problems and having predictive capability). Elegance, simplicity and parsimony can also be significant factors in gaining support for a theory. Moreover, practitioners are expected to display and practice certain personal values: objectivity, rationality, intellectual integrity, accuracy, diligence, open-mindedness, self-criticism, scepticism and circumspection (in the sense of suspending judgement until all the evidence is in hand). In addition, they are expected to be dispassionate and disinterested.

Critical questions are asked by other practitioners about the appropriateness, extent and accuracy of the data, how it was collected and interpreted and whether the conclusions follow directly from the data. The explanation is scrutinized for internal consistency and for consistency with other accepted theories. Particular attention is directed to the background theory and assumptions underpinning the research design, and to the deployment of auxiliary theories and choice of instrumentation and measurement methods.

Once students have recognized that scientific inquiry is influenced by the sociocultural context in which it is located, the obvious next step is to direct their attention to the ways in which science and technology are influenced by particular sectional interests and the ways in which the norms and values of scientific practice are sometimes subordinated to commercial interests or even violated in pursuit of them. The intent is to assist students to look critically at the kind of science and technology in which we engage and the social, political, economic and moral-ethical values that drive development, and to ask what can and should be changed in order to achieve a more socially just democracy and to ensure more environmentally sustainable lifestyles. This view of science education is overtly and unashamedly political. It whole-heartedly endorses the views expressed some twenty years ago by the authors of Education for Citizenship and the Teaching of Democracy in Schools (QCA, 1998).

Not just education about citizenship, but education for citizenship... citizenship education is education for citizenship, behaving and acting as a citizen, therefore it is not just knowledge of citizenship and civic society; it also implies developing values, skills and understanding (p. 13, emphasis added).

Recognizing the Political Dimensions of SSI

In Hodson (2011), I discussed the value of an approach that builds students' capacity for sociopolitical action on SSI through a 4-stage model. 
- Stage 1: Appreciating the societal and environmental impact of scientific and technological change and recognizing that science and technology are, to some extent, culturally determined.

- Stage 2: Recognizing that decisions about scientific and technological development are taken in pursuit of particular interests and that benefits accruing to some may be at the expense of others. Recognizing that developments in science and technology are inextricably linked with the distribution of wealth and power.

- Stage 3: Addressing controversy, clarifying values, resolving ethical dilemmas, formulating and developing one's own views and justifying them through discussion and argument.

- Stage 4: Preparing for and taking action on socioscientific and environmental issues

In the first stage, case studies of major technological innovations such as the steam engine, the internal combustion engine and/or the computer are ideal for tracing the social and economic factors that drive innovation and for raising awareness of the ways in which technology shapes the lives of people, impacts significantly on the environment and can sometimes change quite radically the ways in which people think, talk and act. On the latter point, students themselves have lived through and are currently experiencing the massive changes brought about by computer technology and the development of social media. Developments in genetic engineering have questioned our notions of life and death and our views about what is natural and what is artificial and presented us with profound moral-ethical problems. Both developments have posed major challenges to our concepts of freedom, equality, democracy and personal identity.

Well-chosen case studies can show students that technological innovation is complex, far-reaching and not entirely predictable, sometimes bringing unexpected benefits, unanticipated costs and unforeseen risks. The benefits of scientific and technological innovations are sometimes accompanied by problems: the urgent need for many people to develop new skills, challenging and sometimes disconcerting social changes, radical changes in lifestyle, hazards to human health, environmental degradation, major moralethical dilemmas and sometimes restriction rather than enhancement of individual freedom and choice. Technologies almost always develop faster than our awareness of the problems, understanding of the associated ethical issues and development of legal constraints. Realization of the full extent of the hazards often comes very late, as in the case of DDT, CFCs and plastic waste.

Significantly, the impact may primarily affect those with little or no power to protest, organize concerted counter-actions, demand change and/or seek recompense. For these reasons, it is important to ensure that there is wider and more critical scrutiny by a more diverse group of people of our policies and priorities for scientific research and technological development and closer monitoring of all trials and implementations. It is common for the seductive power of new and powerful technologies to blind us to possible unexpected adverse consequences and divert us from consideration of the values that accompany them. More disturbingly, the hazards may be known but they are ignored (or even suppressed) because it is more convenient (and profitable) to maintain the status quo and hope that problems will go away or will be solved by new scientific discoveries or technological innovations.

Innovations in information and communications technology, such as mobile phones, email and the Internet have created opportunities, possibilities and dangers that would have been unimaginable two decades ago. Cheap, lightweight and "go anywhere" technologies have shifted, broadened, fragmented and redefined the basis of communicative power and shown that governments, NGOs, business corporations and the military can no longer exploit public ignorance or exert absolute control over news and information. There is no longer a gulf in time between an event and the emergence of an account of those events, during which the story can be edited and manipulated to reflect particular interests. Within minutes, the public has access to vivid and authentic impressions of what is happening, even in remote parts of the world. There is no longer time for governments and other interested parties to pre-empt, mediate or suppress information.

Because these new portable technologies are available to almost everyone, a new capacity for instant scrutiny and an attendant call for greater accountability have emerged, as graphically illustrated a few years ago by the Freddie Gray episode in Baltimore (see www.democracynow.org). New modes of 
communicative design have created a space for alternative politics, cultures and voices and have created new opportunities for collective intervention to address common issues and problems. At the same time, however, they have substantially increased the ability of employers and governments to monitor the communications and activities of employees and citizens, creating some major problems of privacy and ownership. Because email messages are assigned traceable number codes, almost any message can be tracked and made available to others, possibly in modified form, as Edward Snowden's revelations have shown (see www.democracynow.org; www.theguardian.com).

At the second curriculum stage, the goal is to help students recognize that scientific and technological decisions are usually taken in pursuit of particular interests, justified by particular values and sometimes implemented by those with the economic or political power to override the needs and interests of others. Hence, students should be encouraged to ask a series of key questions about every scientific or technological innovation. Why is this particular scientific research funded and this technology pursued? What is the underlying rationale and justification for these decisions? What are the perceived social, economic and environmental effects? What moral-ethical issues are raised, and what adverse impacts are likely? Who are the key stakeholders? What are their interests? Whose voices are heard and whose are marginalized or ignored? What intentions or motives guide the decision-making? Who benefits? Who is harmed? Is this just and equitable? Does this decision promote the common good and serve the needs of environmental protection? Should we support or oppose this development?

Answering these questions often reveals that science and technology serve the rich and the powerful in ways that are prejudicial to the interests and well-being of the poor and powerless, sometimes giving rise to further inequalities and injustices. For example, the garbage from urban consumption in affluent Western countries is sent to incinerator plants, waste dumps and landfill facilities located overwhelmingly in urban and rural communities of colour, poverty and social disadvantage. The wealthy can reduce their level of risk and exposure to toxic effluent by moving to new homes; the politically powerful can do so by ensuring that the installation is cited elsewhere; the poor and the powerless are exposed to the hazards and have to suffer the problems.

From an international perspective, it quickly becomes clear that the material benefits in the West (North) are often achieved at the expense of those living in the developing world (South), with the consumptionoriented lifestyle in the industrialized nations creating contaminated environments that impact disproportionately on those people least able to protect themselves. For example, as Agyeman and Carmin (2011) and Bisschop (2014) report, much of the e-waste generated in the European Union is exported to dump sites in West Africa, South-East Asia and India, where it is often dismantled by poorly equipped and ill-protected workers and scavengers, including many children in search of scrap metal. The remaining material is usually burned or dumped into unprotected sites, resulting in substantial contamination of air, water and soil by lead, cadmium, phthalates and chlorinated dioxins, all of which have carcinogenic properties and adverse neurological impact (Greenpeace, 2008).

The frequency with which environmental degradation impacts the poor, disadvantaged, marginalized and powerless much more than the rich and powerful warrants use of the term environmental racism. For example, substances deemed dangerous to the environment, and hence banned in countries of the rich North, are still exported to developing countries in the economically challenged South, while pharmaceuticals banned in the industrialized countries are often sold, distributed and used in developing countries because they are profitable to the manufacturers. Highly toxic waste is routinely shipped from Europe and the USA, where it was created, to impoverished countries like Guinea-Bissau and Sierra Leone in exchange for economic aid (Ibitavo, 2008).

For many years, industrial installations located along the US-Mexico border (known locally as maquiladoras) routinely dumped toxic waste into sewers and rivers, including those from which local communities obtain their drinking water. In the border cities of Brownsville (Texas) and Matamoras (Mexico) the incidence of children born with anencephaly, that is, born without a forebrain, is four times the national average. Bullard and Johnson (2000) report that affected families have filed lawsuits against 88 of the area's 
100 maquiladoras for exposing the community to xylene - thought to be the cause of these birth defects and known to cause brain haemorrhages and lung and kidney damage. Minaya and Downing (n.d.) have since reported that many of the lawsuits were settled out of court and much stricter controls on dumping of toxic waste have been established, although they note that local community activists, health professionals and the more outspoken employees of the maquiladoras allege continuing disregard of regulations.

Further issues concern the role-played by Western governments and business interests in controlling the production and distribution of resources in developing countries, including examples of the systematic appropriation of land and water resources for producing cash crops for export to the West, often resulting in lower prices for farmers, increased vulnerability of crops to pests (and the consequent increased reliance on chemical controls), soil impoverishment and top soil depletion, increased poverty, insecurity and eventual dispossession. Developing countries are often forced to accept Western technology and Western agricultural practices, including widespread use of fertilizers to increase crop yield, herbicides and insecticides for weed and pest control, mechanized farming and irrigation practices, and even adoption of genetically engineered crops, in exchange for other forms of economic aid and military support. Such high-cost inputs may not be affordable or ecologically sustainable.

Chopra (2009) describes how the introduction of the agribusiness methods of developed countries, including widespread use of chemical fertilizers, pesticides, growth hormones and antibiotics, extensive forest clearance, introduction of genetically modified plants and animals and the recycling of slaughterhouse refuse as animal feed has had disastrous ecological impact in many parts of India. The water table has dropped to alarmingly low levels; the earthworm population has been devastated, with major adverse impact on the quality of topsoil; many species of bees, butterflies and birds, essential to the pollination process, are in serious decline; nitrogen-fixing bacteria are almost extinct; and the numbers of insect eaters such as frogs and lizards are much reduced, with consequent decline in the numbers of predators that feed on them (eagles, hawks, etc.) and the vultures that dispose of the "leftovers". Equally disastrous has been the negative impact on the lives of subsistence farmers.

\section{Addressing Controversial Issues}

Curriculum stage three focuses on supporting students in dealing with controversial issues rationally, diligently, tolerantly and morally, formulating their own opinions on important and often controversial issues and establishing their own value positions. This phase is also about becoming committed to the fight to establish more socially just and environmentally sustainable practices and building the confidence, mindset, insights and skills necessary for effective and responsible change advocacy and change agency. It focuses much more overtly than traditional STS and STSE education on scrutinizing diverse views, analyzing and evaluating them, recognizing inconsistencies, contradictions and inadequacies, reaching their own conclusions, clarifying values, developing strong feelings about issues, arguing coherently and persuasively for their views and actively thinking about what it means to act wisely, justly and "rightly" in particular social, political and environmental contexts.

It has much in common with the goals of Peace Education, Multicultural and Antiracist Education, Global Education and Humane Education. It begins with fostering self-esteem and personal well-being, welcoming and attending to diversity in ideas, opinions, perspectives, practices and values, concern for the welfare of others, respect for the rights of others, building empathy and mutual trust, the pursuit of fairness, equity, justice and freedom, cooperative decision-making, creative resolution of disagreements and conflict between individuals, within and between communities, and throughout the world. It is driven by a deep commitment to anti-discriminatory education - that is, exposing the common roots of sexism, racism, homophobia, speciesism, Eurocentrism and Westism (or Northism) in the tendency to dichotomize and generate a sense of other, and working actively to confront the "us and them" mentality that invariably sees "us" as the norm, the desirable and the superior. It culminates in a commitment to the belief that alternative 
voices can and should be heard in order that decisions in science and technology reflect wisdom and justice, rather than powerful sectional interests. Maxwell $(1984,1992)$ defines wisdom as the capacity to realize what is of value in life for oneself and others. He continues as follows:

In a world in which international affairs are conducted at the intellectual and moral level of gang warfare (as they all too often are), the mere provision of new knowledge and technology, dissociated from a more fundamental concern to help humanity resolve its conflicts and problems of living in more cooperative ways, is an obvious recipe for disaster. It merely increases our power to act, without at the same time increasing our power to act humanely, cooperatively and rationally... We urgently need a new, more rational kind of academic inquiry, which gives intellectual priority to the tasks of articulating our problems of living, proposing and critically assessing possible cooperative solutions. (Maxwell, 1992, p. 207)

Many SSI are highly controversial, sometimes because the scientific information required to formulate a judgment about them is incomplete, insufficient, inconclusive or extremely complex and difficult to interpret and sometimes because judgement involves consideration of factors rooted in social, political, economic, cultural, religious, environmental, aesthetic and/or moral-ethical concerns, beliefs, values and feelings - concerning which, people may hold widely varying positions. In other words, controversy may be internal or external to science. Once a decision has been made to include externally controversial issues in the curriculum, teachers have to decide the most appropriate way to address them. Should they take a neutral position, adopt the devil's advocate role, try to present a balanced view or advocate a particular position? One form of neutrality, affirmative neutrality, describes a situation in which teachers present multiple sides of a controversy without revealing which side they support. In procedural neutrality, information about the controversy and different points of view are elicited from the students, possibly after opportunity for library-based or Internet-based research. Quite apart from the danger of encouraging relativism, where any idea is accepted as long as it is someone's opinion, neutrality is a position that seriously threatens the teacher's credibility as critic, guide and mentor, and invites the reasonable question: Do you not have a view, Miss? It is absurd for teachers to pretend that they do not have a view; it is deplorable for teachers to refuse to state that view while encouraging or even requiring students to state theirs.

The notion of even-handedness or presenting a supposedly balanced view is also extremely problematic. What counts as balance? Whose judgement of balance and whose selection of perspectives is to count? Who decides what counts as relevant or not relevant, accurate or inaccurate, admissible or inadmissible, important or unimportant? Who decides what should be regarded as facts and what is deemed to be opinion? If all students express a similar view, where will alternatives come from? The notion of even-handedness seems to require teachers to give equal time, consideration and weight to views and arguments that are clearly not of equal merit and prevents students from developing the critical skills necessary for judging the worth and validity of different positions.

Some years ago, Kelly (1986) argued for committed impartiality, in which teachers present multiple sides of an issue or argument and, at some stage, share their own views with the class. In my view, it is crucial that teachers help students to identify, clarify and challenge the assumptions of all positions (including their own and the teacher's), acknowledge the influence of sociocultural context, religious beliefs, emotions and feelings, address issues of rationality, equity and social justice, and engage in group-based critical reflection. When students are encouraged to debate and challenge all views, including their teacher's, they not only develop critical discussion skills but also build the courage essential for social commitment. 
Addressing Ethical Concerns

Discussion of SSI raise questions not only about what we can or could do but also about what is the right decision and what we ought to do, thereby raising some central ethical dimensions. Recent developments in biotechnology, for example, raises many important questions and concerns about whether certain lines of research should be permitted. Should any individual with a disabling genetic condition be able to have gene therapy using material from embryonic stem cells? Should prenatal genetic testing be readily available and selective abortion of a fetus with a genetic disorder be permitted? Parents can already choose the sex of their child; soon, it may be possible to isolate and remove genes that increase the likelihood of schizophrenia, obesity, alcoholism, ADHD and a host of fatal or disabling conditions. Should such genetic engineering be permissible? It might soon become possible for prospective parents to choose the colour of a child's hair and eyes or to select any other characteristics they regard as desirable. These actions would put value on one kind of person at the expense of another - a clear eugenic intent. Should this be permissible? Should there be constraints on the work of Craig Venter, which shifts the focus from reading a genetic code to writing one - that is, not just modifying an existing organism to ensure "more favoured characteristics" but making an entirely new one (see www.jcvi.org andwww.tigr.org)?

Because we live in an increasingly pluralist society, we cannot assume a shared set of moral values, so reaching agreement is likely to be difficult. One response is to allow the views of the majority to prevail-a position that necessarily disregards or marginalizes the needs, interests, values and rights of minorities. Even critical discourse between and among all interested parties may fail to bring about consensus, and if consensus were reached there would be no guarantee that it had reached the right answer. Ascertaining the right answer (what we ought to do) raises questions and concerns about morality (what it is right or wrong to do) and ethics (the reasons and justifications for judging these things to be right or wrong). I am certainly not arguing that students follow a rigorous course in moral philosophy, any more than I would advocate the promotion of a morality based on a particular religion or set of laws and cultural precedents, but I do advocate that they be equipped with some intellectual tools for addressing and resolving contentious issues that cannot be solved solely by scientific, economic or environmental considerations. At the very least, students need some basic understanding of egoism, consequentialist notions (including utilitarianism), deontological ethics, social construct theory (or social contract theory) and virtue ethics (BonJour \& Baker, 2007; Hursthouse, 1999; Singer, 1991).

Fullick and Ratcliffe (1996) describe a number of strategies that can help to direct student attention to the ethical concerns embedded in SSI and assist them in dealing with ethical dilemmas in a systematic and rational way. Strategies include the following: (i) consequence mapping or future wheels (through which students are asked to consider a range of personal, social, economic, legal, environmental and ethical implications surrounding an issue and the possible responses to it); (ii) goals-rights-duties frameworks (for each player or constituency involved in a controversy, students consider the intentions, rights/expectations and obligations towards others and the environment); and (iii) group discussions around carefully focused questions (oral or written questions direct student attention to the nature of the problem, possible solutions, reasons why one solution may be preferred to another, and stimulate reflection on students' own value positions).

The New Zealand Biotechnology Learning Hub (www.biotechlearn.org:nz) provides support for students addressing ethical issues in the form of two interactive thinking tools. The ethics thinking tool enables students to structure and evaluate their ideas in relation to four sets of ethical guidelines: benefits and harms; rights and responsibilities; freedom of choice; virtues. The futures thinking tool encourages students to consider the existing situation, analyze trends, identify the driving forces and causes of those trends, identify possible and probable futures, and select preferred futures. Use of these tools, together with a wide range of other teaching and learning strategies, is discussed by several authors in the edited collection: Ethics in the Science and Technology Classroom (Jones et al., 2010). 
Stem cell research poses a whole raft of ethical problems on which students can exercise their developing skills (France et al., 2012; Halverson et al., 2009). First, an important distinction can be drawn between adult stem cells derived from blood, bone marrow, fat and other tissues, and embryonic stem cells from discarded in vitro fertilization (IVF) cultures, aborted fetuses or embryos created in the laboratory. Embryonic stem cells are more plentiful and easier to extract; they can be grown and made to multiply in the laboratory more easily; they are more pliable and so have much more regenerative potential. In short, they are of much greater value in research and more likely to result in the development of innovative medical treatments. However, for some people, the distinction between embryonic stem cells and adult stem cells also constitutes a boundary between ethically acceptable and ethically unacceptable practice. For others, the boundary may lie in the distinction between stem cells from IVF discards and those from embryos cloned specifically for research purposes. Those who draw the ethical distinction at this point argue that using cells from embryos leftover from IVF treatments, which otherwise would be destroyed, is substantially less objectionable than cloning an embryo in order to harvest its cells, and then destroying it. Ultimately, the debate hinges on the philosophical issue of what constitutes a human being and the ethical issue of whose rights should have priority. Does human life begin at the point of conception, at the moment of implantation in the uterus, at the onset of the development process, at the point when a backbone and organs begin to develop or at the point when the fetus is capable of survival outside the mother, with or without sophisticated technological support? These issues are much more complex than the issue of the relative rights of mother and fetus that students will (or might) have addressed in discussion of abortion.

On a closely related issue in agriculture, students might be asked to consider why the deployment of genetically modified (GM) plants is being extensively promoted by multinational companies like Monsanto (Knight, 2009). Is it because agricultural production cannot be maintained at levels necessary for meeting the nutritional needs of the burgeoning world population? Is it because so much of the annual harvest is lost to the pests and diseases that GM plants can be designed to resist? Or is it because increasing dependence of farmers on GM plants is in the financial interests of the companies holding the patents? Students might be asked to consider the environmental risks that would inevitably follow from the loss of genetic richness and variance, and whether such risks should be taken without more widespread public consultation. They might look into the possibility of unanticipated risks, particularly mutations and extinctions arising from interactions of GM plants with insects and other plants.

With regard to risk assessment, students might consider the likely effectiveness of protocols for ensuring that environmental risks associated with the introduction of transgenic organisms are minimized. They might consider who would set the procedures and standards, and whether it is likely that the protocols would be faithfully performed and monitored by all farmers. Of course, standard risk assessment methods do not address the social risks surrounding the monopolization of the world's food supply in the hands of one or two giant companies and the impoverishment and dislocation of small-scale farming communities, but these are important considerations for presentation to students.

With regard to health issues, students might be asked to consider why drug companies consistently decline to engage in research and development directed towards combating and treating diseases such as malaria, trypanosomiasis (sleeping sickness) and schistosomiasis (bilharzia), while directing massive resources towards research on heart disease and cancer. Students' attention should be directed towards the ways in which commercial interests often influence the way research findings are made public (press conferences rather than publication in academic journals, for example) and the ways in which the impact of adverse data is minimized, marginalized, hidden or ignored. For example, in publicizing the value of oral contraceptives and hormone replacement therapy, the increased risks of cervical cancer, breast cancer and thromboembolism are often given little attention.

Following critical scrutiny of 70 research articles focused on calcium channel blockers (CCBs) used to treat hypertension, Stelfox et al. (1998) concluded that there was a strong association between authors' opinions about the safety of CCBs and their financial relationships with pharmaceutical manufacturers. Underhand tactics sometimes go way beyond manipulation of public opinion through the press. For 
example, in 2001, TAP Pharmaceuticals was fined \$875 million USD for health care fraud in relation to its anti-cancer drug Lupron. Angell (2004) reports that charges to which TAP pleaded guilty included bribing doctors with televisions, VCRs, trips to resorts, cash in the form of "educational grants" (to be used for any purpose whatsoever) and free or heavily discounted drugs, for which the physicians were encouraged to bill Medicare at the full commercial price.

In September 2009, Pfizer was fined \$ 2.3 billion USD for providing financial rewards and other inducements to encourage general practitioners to prescribe drugs for uses not approved by the FDA, principally the use of Bextra (a drug developed to treat arthritis) as a general analgesic. Interestingly, the drug has now been withdrawn from use altogether. Other charges related to misuse of the antipsychotic drug Geodon, the antibiotic Zyvox and the epilepsy treatment drug Lyrica. In 2012, GlaxoSmithKline (GSK) was fined \$3.0 billion USD for bribing doctors and encouraging prescription of unsuitable antidepressants (Paxil) to children. The following year, the company incurred a \$229 million USD for improper marketing of diabetes drug, Avandria, and in 2014 incurred a penalty of \$490 million USD following admission to a charge of bribing Chinese physicians to prescribe GSK products.

In October 2019, the US drug firm Johnson \& Johnson was ordered to pay $\$ 8$ billion USD in punitive damages to a man for failing to warn him that the psychiatric drug Risperdal, which he had been prescribed as a minor, could cause gynecomastia — enlargement of glandular breast tissue. Two months earlier, the company had been fined $\$ 572$ million USD by an Oklahoma judge for "fuelling the opioid addiction crisis" in the state (www.marketwatch, August 2019). The case against Johnson \& Johnson is one of more than 2,000 complaints that have been brought up by municipalities against pharmaceutical companies over opioid abuse nationwide. According to Oklahoma's Attorney-General Mike Hunter, 4653 people died in opioid-related deaths in the ten years 2007 to 2017. He stated that Johnson \& Johnson had created "the worst man-made public health crisis in the history of our country and the state", accusing the company of carrying out a "multi-billion-dollar brainwashing campaign" to get doctors to overprescribe the drug (reported by $C N B C$ on August 26, 2019, and by bbc.com/news/business on August 27, 2019). Judge Thad Balkman said prosecutors had successfully demonstrated that the company contributed to a "public nuisance" through its deceptive advertising of highly addictive prescription painkillers (reported by The Guardian on August 26, 2019). Of course, given that the \$572 million USD in damages represents just 3.7 $\%$ of the company's net profit for 2018 , the fine is little more than a hand-slap.

\section{Engaging Emotions, Managing Emotions}

Personal investment in an issue and commitment to problem-solving and action derive, in part, from emotional involvement. The stronger one's emotional involvement, the more likely one is to take positive action - a situation that is well illustrated in students' responses to SSI when they impact directly on their own lives, or those of family members and people in the local community. However, some SSI are remote from students' immediate lives, making generation of interest, concern and commitment to challenge the status quo more difficult. Reliance on secondary experience, information and knowledge, which is likely to be the case for many students for many SSI, removes them emotionally from the issue and is likely to result in non-involvement and non-action. It is easy to react to sudden and catastrophic changes brought about by earthquakes and tsunamis, but environmental degradation and climate change are both slow and cumulative. There is a tendency, therefore, to over-estimate the long-term significance of hurricanes and earthquakes and seriously under-estimate the long-term significance of small increases in the mean temperature of the oceans.

Large-scale, global environmental problems (such as ozone depletion, loss of habitat and greenhouse gas build-up) are not immediately tangible. We do not see it happen and so it "slips off the radar". The long time lag between the emission of greenhouse gases and their effects on the climate impedes a proper understanding of the relationship. So, too, the anticipated time lag between any actions taken to reduce emissions and the positive effects they might produce. For many people in the affluent West/North, tangible impact is 
elsewhere: melting ice caps in Antarctica, rising sea levels in the islands of the South Pacific, pollution of waterways in China.

For many people, the fact that the effects are not uniform across different parts of the world seems to be at variance with predictions that associate climate change with a mean increase in temperature across the globe. Moreover, predictions by the IPCC and other bodies lose precision at finer geographical scales and so may seem to contradict local experience (González-Gaudiano \& Meira-Cartea, 2010). Thus, environmental degradation and climate change are seen as distant or future problems, not immediate and local ones. Despite repeated warnings from climate change scientists that the longer we delay measures to reduce greenhouse gas emissions the deeper and more irreversible will be the consequences, significant action at the political level is not forthcoming. Many aspects of SSI relating to health, resource use, industrial practice and information technology may also seem distant to students.

Making these issues real means finding ways to stimulate, provoke, irritate, offend, outrage, amuse or delight students as a way of gaining their attention and building involvement and commitment. We need to find ways to make the impact more real, to precipitate feelings of fear, anger, sadness, pain, empathy, compassion and guilt, and link them to positive feelings of agency, control and empowerment. Emotional involvement can be fostered through case studies, drama and role-play, literature, art, photographs, movies and music, site visits, interviews with those directly impacted and so on. Interestingly, Lester et al. (2006) have shown that carefully designed writing activities can also play an important role in developing personal investment in an issue and in increasing students' awareness of the need for sociopolitical action, especially when students assume the role of investigative journalist.

Site visits (hospitals, factory farms, laboratories, etc.) and guided experiences in areas of ecological significance can play a profound role in raising awareness and engaging emotions. Best of all, of course, is direct engagement with locally based issues, as discussed below. It is important to note that informal learning experiences seem to be much more effective than formal schooling in bringing about awareness of issues, attitudinal shifts, values reorientation and willingness to engage in sociopolitical action.

A sense of wonder and feelings of empathy, respect and compassion towards other living things can also be fostered by such easily organized activities as investigating a rock pool, noting what lives in a wall or hedgerow, taking digital photographs to examine the feathers of birds in a suburban garden, watching a spider spin a web, observing insects through a magnifying lens or pond water under a microscope (see Lindemann-Mathies (2005) for further suggestions along these lines). Nor should we under-estimate the value of caring for pets, growing vegetables, observing activity in an ant colony and watching the dramatic events in the life history of frogs and butterflies. An important part of these experiences is the delight that students experience in becoming absorbed in their observations, the feelings of surprise at seeing the world in new ways, the thrill of encountering previously unfamiliar living organisms and habitats, recognizing new possibilities and seeing new relationships (Liston, 2004). Girod et al. (2003) refer to this kind of experience as "re-seeing".

Re-seeing is an attempt to focus our perception on the nuance and detail of the world. Re-seeing requires that we look carefully when we might be tempted to assume we see everything. Re-seeing is also a disposition that causes us to ask questions of what we perceive, such as "What's really going on here?" "Why do things look the way they do?" And "What kinds of things do I need to know more about to really re-see this?" (p. 579)

There is substantial evidence of the power of television, movies, stories, drama, role-play, multimedia materials and language-based activities of various kinds to stimulate interest in an issue, provoke an emotional response, present alternative positions, challenge values and precipitate debate. Stories juxtapose different opinions, voices and perspectives, encouraging the reader (or listener) to deliberate, evaluate and decide on where they stand, or to adopt a different stance. Through stories, and especially through drama, 
students are stimulated to address issues and events from the perspectives of others, explore and develop understanding, establish new relationships and consolidate existing ones. In other words, engaging with narrative is as much a way of knowing ourselves, as it is a way of understanding the views of others. Improvised drama enables students to enrich these explorations with personal experiences, thoughts and linguistic preferences.

Poetry is an especially powerful means of generating emotional response and provoking the shift of perspective encapsulated in the notion of "re-seeing". Encouraging students to write poetry and stories creates opportunities for them to explore their ideas, express them in less formal language, manipulate and critique them by placing them in the mouths of others, explore ambiguity and uncertainty, wrestle with dilemmas and, crucially, express the way they feel about their ideas and the ideas of others.

\section{Learning to Act}

The final (fourth) stage in this issues-based approach is concerned with students seeking ways to put their values and convictions into action, helping them to prepare for and engage in responsible action and assisting them in developing the skills, attitudes and values that will enable them to take control of their lives, cooperate with others to bring about change and work towards a more just and sustainable world in which power, wealth and resources are more equitably shared. It is not enough for students to learn that social, political and economic forces influence science and technology; they need to learn how to participate and they need to experience participation. Moreover, they need to encourage others to participate, including parents, grandparents, friends, relatives, neighbours and local businesses. It is not enough for students to be armchair critics! As Kyle (1996) puts it:

Education must be transformed from the passive, technical, and apolitical orientation that is reflective of most students' school-based experiences to an active, critical, and politicized life-long endeavour that transcends the boundaries of classrooms and schools. (p. 1)

I am acutely aware that my own generation of WWII children and the subsequent generation of baby boomers grew up in a very different world from 2020. During the 1960s, we were blissfully unaware of the extent and pace of environmental degradation; jobs were plentiful; ambitions were high, and despite the constant threat of nuclear annihilation and daily news bulletins about the evils of the Vietnam War (or American War as the Vietnamese call it), the social climate was one of optimism for the future. Young people were confident that desirable change could be brought about by collective action (marches, demonstrations, petitions and the like), as illustrated by the lyrics of many of the pop songs of the time. The following five decades saw a marked decline in social activism and levels of public participation, such that, during my 40+ years as a teacher and teacher educator, I became increasingly saddened at the lack of political interest among teachers and students, disturbed by their complacency and easy acceptance of the status quo, concerned by the apathy of teachers regarding the values implicit and explicit in the curriculum they deliver, and disappointed with their lack of courage to fight for a more engaging and socially relevant science education. Political apathy was increasingly widespread, many citizens lost faith and trust in politicians and opportunities to participate in key decision-making declined substantially, coincident with the rise of mega-corporations and the increasingly convoluted bureaucracies of local, regional and national governments.

For some time, I have been contemplating how we can turn back the clock and re-establish the view that we can, should and will strive to change the world for the better. Now, there appears to be a massive shift in the outlook of young people, stimulated by the examples set by Greta Thunberg, Malala Yousafzai and the Parkland School students. Indeed, according to the Guardian newspaper, some 1.4 million young people 
participated in the Global Climate Strike on March 19, 2019, and an estimated 6 million were involved in the Global Week for the Future in September 2019. Accurate data for the number involved in the Black Friday for Action on Climate Change were not available at the time of writing. Maybe now-finallyschools have a level of interest and commitment among students on which to build the kind of school science curriculum these young people deserve.

The current generation of teachers can play a key role in reversing the long-running decline in civic participation and firing up students currently in school to seize opportunities to cultivate a sense of community, develop an awareness of ties to others, recognize their obligations and responsibilities to establish, support and sustain politically active communities, work together, take greater responsibility and engage in activities designed to effect change. With this in mind, I have re-ignited my attraction to Elam and Bertillson (2003) notion of the radical scientific citizen.

The radical scientific citizen is fully prepared to participate in demonstrations... street marches, boycotts and sit-ins and other means of publicly confronting those ruling over science and technology... While the scientific citizen as activist may be taking a partisan position in defence of a particular individual or group in society, they are also understood as assuming a moral stance in defence of general ethico-political principles... which are accepted as existing through many different and conflicting interpretations... and subjecting them to continuous contestation. (p. 245)

Students will only become activists if they feel personally empowered to effect change, believe that they can make a difference and know how to do so. Moreover, the likelihood of students becoming active citizens is increased substantially by encouraging them to take action now (in school), providing opportunities for them to do so, and providing detailed examples of successful actions and interventions engaged in by others. Suitable actions include the following: making public statements, building informative websites and publishing newsletters, writing to newspapers, organizing petitions and community meetings, working for local action groups and citizen working groups, making posters, distributing leaflets, demonstrating, making informative multimedia materials for public education, disseminating advice to householders, farmers and local industries on safe disposal of toxic waste, generating data for community groups such as birdwatchers and ramblers, establishing neighbourhood Nature Watch initiatives, instituting recycling programmes for glass, paper and aluminium cans, organizing consumer boycotts of environmentally unsafe products and practices, working on environmental clean-up projects, creating nature trails, conservation ponds and butterfly gardens, planting trees, building a community garden, setting up a garbage-free lunch programme, assuming responsibility for environmental enhancement of the school grounds (including planting of indigenous species and encouragement of biodiversity), monitoring the school's consumption of energy and material resources in order to formulate more appropriate practices (including use of solar panels, for example), reducing water consumption through recycling schemes, monitoring the use and disposal of potentially hazardous materials within the school, setting up a Green Purchasing network.

It is sometimes useful to distinguish between direct and indirect action. The former includes such things as recycling, cleaning up a stream or a beach, using a bicycle rather than a car or bus, switching off lights and using reusable and recyclable bags at the supermarket; the latter includes compiling petitions, distributing leaflets, writing to newspapers and making submissions to the local council. While direct action can be enormously important and can have some significant impact, it can also divert attention from the root causes of the problem under consideration. It fails to confront the real causes and agents of environmental degradation, avoids critique and questioning of our social, political and economic activities.

In other words, it depoliticizes problems and shifts the burden of responsibility onto individuals and families and away from governments, corporations, the policies that might have long-term and significant impact and the political negotiations that might lead to change. Cleaning up a beach will have immediate beneficial impact, of course, but without an investigation of the causes and appropriate intervention aimed at those causes, there will be no long-lasting solution. Setting up a recycling programme may prolong the 
active life of one or two landfill sites but it does not address (and it certainly does not change) the unsustainable economy of resource use, production and consumption. Investigating nitrate and phosphate pollution levels in waterways is an important activity; boycotting chemically based agricultural products and promoting the use of organic fertilisers may have more impact on the environment; conducting an analysis of the waterways, publicizing the data arising from it, identifying the likely cause of the pollution as run-off from local farms and parks, alerting farmers, ground maintenance staff in sports facilities, park keepers and domestic gardeners to both the causes and the adverse environmental impact of chemically based products, making them aware of organic alternatives, and encouraging farm suppliers and garden centres to promote those organic alternatives is the ideal.

Preparing students for action necessarily means ensuring that they gain a clear understanding of how decisions are made within local, regional and national government, and within various social groups, industry, commerce and the military. Without knowledge of where and with whom power of decisionmaking is located, and awareness of the mechanisms by which decisions are reached, intervention is not possible. Students need to identify action possibilities, assess their feasibility and appropriateness, ascertain constraints and barriers, resolve disagreements among those who will be involved, look closely at the actions taken by others (and the extent to which they have been successful) and establish priorities in terms of what actions are most urgently needed (and can be undertaken fairly quickly) and what actions are needed in the longer term. It is essential, too, that all actions taken by students are critically evaluated and committed to an action database for use by others. From a teaching perspective, it is important that care is taken to ensure both the appropriateness of a set of actions for the particular students involved and the overall practicality of the project in terms of time and resources.

\section{Learning About, Through and From Action}

Distinctions among learning about action, learning through action and learning from action (McClaren \& Hammond, 2005) can be helpful in planning interventions. Learning about action focuses on learning the skills and strategies of sociopolitical action through movies, biographies and autobiographies, case studies and simulations, role-play and dramatic reconstructions. Providing students with examples of successful action taking, preferably involving other students, fosters the belief that they can change things, too. It is here that an action database can be especially useful. Students can learn from the experiences of othersthat is, listening to and/or reading the stories of those who have been intimately involved in such projects and detailed accounts of individual, group and community-based actions.

Schusler et al. (2009) provide much helpful advice on how researchers can go about gathering this kind of oral history by asking questions such as: What motivated or inspired you to engage in this kind of work? What were your goals, hopes and expectations? How did this project come about? Who has been involved? What barriers and problems were encountered? How were they addressed? What successes have there been? What failures have there been? What have you learned? What surprised, delighted or disappointed you? What would you do differently if you were starting again? Would you do it again?

Learning through action comprises direct involvement in action-oriented projects outside the classroom that are likely to have tangible outcomes and consequences. While some projects may be chosen and organized by the teacher, especially in the early years, it is important to involve students as quickly as possible in selecting and planning for themselves the actions to be taken. It is important to involve students in local SSI-oriented research activities and support them in participating in community-based organizations that bring citizens together to grapple with serious local issues, particularly those issues often overlooked by government agencies. In confronting real local issues directly, students gain valuable first-hand experience of the ways in which competing social, political and economic interests can impact decision-making. Through participation in community-based activities, they gain access to ideas, experiences, people, institutions and sociopolitical structures that build both individual and collective capacity to address SSI 
and environmental issues in a responsible, thoughtful, critical and politically effective way, and build the commitment to engage in the struggle for greater freedom, equality and social justice. By engaging in public issues at the local level, students see democratic processes in action; by working alongside others, they learn about the demands and difficulties of taking action and learn to develop effective coping strategies.

Research suggests that participation in these kinds of activities in childhood and adolescence is associated with levels of civic participation, community service and political activism in adulthood up to four times higher than the norm (Chawla \& Flanders Cushing, 2007). Through involvement in public hearings and town hall meetings, consensus conferences, study circles, focus groups, citizen juries/panels, negotiated rule-making forums and public/citizen advisory committees, students gain autonomy, a sense of worth and competence, a sense of personal and civic identity, respect for other people's views, negotiation skills and so on. By working on a sub-task within a group effort, individuals acquire a level of expertise that would not be achieved alone, at least not so quickly and so painlessly. They also come into contact with perspectives on issues and problems that differ from their own. Sharing experiences, action strategies and success stories, as well as building friendships, can be inspirational and highly motivating, and can lead to lifelong sociopolitical activism.

Learning from action occurs when students evaluate the plans, strategies, processes and outcomes of their own action projects and those of others. Debriefing entails compilation of a record of what happened or what the students perceive to have happened, attempts to identify why (or why not) the action was successful, and reflection by all parties on the significance of the action for themselves and for the community. The process is facilitated by keeping careful logs and journals, consulting with others, sharing experiences and feelings, and communicating with all those involved. It is important that a particular action is not viewed as an end in itself. Students need opportunities to evaluate the action taken, reflect on its nature and impact and possibly reformulate the action. The simple point is that a positive orientation towards sociopolitical action is established over time and is rooted in reflective practice.

Students can gain experience of action, and thereby learn through action and learn from action via the familiar three-phase apprenticeship approach comprising modelling, guided practice and application —as discussed above. By engaging in interventions and action-oriented projects alongside a trusted and skilled critic, students increase both their understanding of what constitutes sociopolitical action and their capacity to engage in it successfully. In other words, social activism is a reflexive activity: current knowledge and expertise informs and determines the conduct of the activity and, simultaneously, involvement in actions (and critical reflection on them) refines knowledge and sharpens expertise. Throughout these activities, the teacher's role is crucial: model activist, advisor, learning resource, facilitator, consultant, emotional support and critic. Also, because students are given the opportunity to experience failure as well as success, it is imperative that the class atmosphere is both forgiving and supportive and there is continuing dialogue about the way the activity is progressing, including frank discussion of problems encountered, avenues that prove fruitless and barriers to progress that prove insurmountable.

Crucial also, if the goal is for students to gain understanding of authentic sociopolitical action, is constant comparison between what students are doing in their project and what others have done. Sperling (2009) urges teachers to introduce students to the idea of SMART plans-that is, plans that are Specific, Measurable, Attainable, Realistic and Timely. Good advice, certainly, but the reality is that the smartest plans in prospect may prove otherwise in practice. And coming to that realization, and seeking to ascertain why the plan proved less than ideal, is a crucial part of the learning experience. So, too, of course, is simply engaging in action. Even though an action may not solve a problem, reach a satisfactory conclusion or have a significant environmental impact, it may still have great significance in terms of personal growth, fostering positive attitudes and building commitment. As well as teaching students the need to be resilient and determined to try again, experiences of failure may also impress upon them the need to mobilize others and to engage in collective action. Collective actions are almost always more effective than individual actions and, in some circumstances, may be the only means of bringing about change. 


\section{Further Considerations}

This article has focused on the kind of science education needed as preparation for taking appropriate, responsible and effective action on matters of social, economic, environmental and moral-ethical concern. The prime purpose of this approach is to enable young citizens to look critically at the society we have and the values that sustain it, and to ask what can and should be changed in order to achieve a more socially just democracy and to bring about more environmentally sustainable lifestyles. In advocating a four-stage model, my intention was not to suggest that all action is delayed until the final years of schooling. Rather, students should proceed to whatever stage is appropriate to the specific SSI under consideration, the learning opportunities it presents and the level of intellectual and emotional development of the students, bearing in mind the simple class management principle of investing each topic with a degree of variety.

In some areas of concern, it is relatively easy for students to be organized for action; in other areas, it is more difficult. For some SSI, stage three is more demanding than stage four. For example, it is easier to take action on recycling than to reach a considered and critical judgement of recycling versus reduced consumption versus use of alternative materials. Furthermore, it is unlikely that all students will be motivated by the same issues, problems, experiences or situations and likely that individuals will vary quite substantially in their disposition to act. Clearly, these differences make it difficult to plan a common action-oriented curriculum for all. But there is no reason why we should expect different students and groups of students to participate in the same project. Different views and different priorities could (and possibly should) lead to involvement in different projects.

Students who have been used to a traditional science curriculum will be familiar with science being presented as entirely rational, systematic, analytical, depersonalized and unemotional, with few opportunities for exploring feelings, emotions and sentiments. When confronted with an SSI-oriented approach, such students may be surprised by their emotional responses to controversial SSI and environmental issues and may be disconcerted by the cut and thrust of classroom debate. If learners lack the capacity to handle emotional upsets or to deal with their impulses, it becomes difficult for them to engage in learning activities, evaluate different options, apply mature and reasoned judgment and take responsibility for synthesizing their views. Of course, students' views and assumptions about SSI addressed in class will be strongly influenced by personal experiences and the experiences of friends and family, and by sociocultural determined predispositions and worldviews. A student's sense of identity, including ethnicity, gender, social class, family and community relationships, economic status and personal experiences extending over many years, will necessarily impact on their values, priorities and preferences.

Rejecting knowledge and beliefs that are strongly held within social groups to which the student belongs, or wishes to belong, may be so emotionally stressful that it becomes virtually impossible. Similarly, accepting views that are in opposition to the dominant views within those groups is likely to be a formidable undertaking. The science teacher's job can be seen, in part, as helping students to gain an understanding of what, for many, are alien cultures (the subcultures of science, school and school science) and to assist them in moving freely and painlessly within and between these subcultures and the subcultures of home and community. It is fair to say that many teachers have seriously under-estimated the difficulties faced by some students. As Lemke (2001) comments, a student:

spends most of every day, before and after science class, in other subject-area classes, in social interactions in school but outside the curriculum, and in life outside school. We have imagined that the few minutes of the science lesson somehow create an isolated and nearly autonomous learning universe, ignoring the sociocultural reality that students' beliefs, attitudes, values, and personal identities - all of which are critical to their achievement in science learning - are formed along trajectories that pass briefly through our classes. (p. 305) 
Teachers introducing SSI into the curriculum need to be sensitive to these influences and will need to assist students in dealing with potentially stressful and disconcerting learning situations. It is here that notions of emotional intelligence, emotional literacy and emotional competence can be helpful. Although these three terms are closely related, Matthews (2005) chooses to draw a distinction between the individualistic nature of emotional intelligence and the strongly social nature of emotional literacy. Thus, he argues, emotional intelligence refers to an individual's ability to perceive, describe, appraise and express emotions, understand emotions and emotional knowledge, access and/or generate appropriate feelings when they facilitate thought, or manage them productively when they might inhibit, while emotional literacy is the capacity to be receptive to a wide range of feelings, empathize with others and continuously monitor the emotional climate in which one is located. Emotional competence may be seen as an amalgam of the two.

In general, the goal of emotional literacy is awareness and management of one's emotions in both joyful and stressful situations, the confidence and self-assurance to understand one's own emotions, and the capacity to deal with them in a positive and intentional way. It is closely related to notions of self-awareness, self-image, self-esteem and sense of identity, and less directly with self-efficacy and agency. These matters are well outside the focus of this article, save to note that emotional involvement can be fostered through case studies, drama and role-play, literature, art, photographs, movies and music, site visits, interviews with those directly impacted by the SSI under consideration, and so on. Writing activities can also play an important role in developing personal investment in an issue and in increasing students' awareness of the need for sociopolitical action, especially when students assume the role of investigative journalist. Site visits (hospitals, factory farms, laboratories, etc.) and guided experiences in areas of ecological significance can play a profound role in raising awareness and engaging emotions.

It is worth noting that young people are more likely to participate in community activities if a parent, some other family member or a close friend is already active and/or expresses approval and gives them lots of support (Fletcher et al., 2000; Pancer \& Pratt, 1999). The prevalence of references by young people to the influence of parents and other role models in forming their views and attitudes is sufficient testimony to the influence of the old on the young. It is also the case that adults are more likely to join activist groups if their children are already involved or have expressed a desire to be involved. Political power rests with adults, but children can influence the ways in which that power is exercised. Consumer power rests (ultimately) with adults, though children can and frequently do exert considerable power on family consumption practices.

Codes of behaviour, language patterns and tastes in music, fashion and movies adopted by young people frequently act, over time, to shift older people's views and behaviours in a similar direction. On a closely related theme, Ballantyne et al. (1998, 2001a,b) have sought to exploit the ability of students to influence their parents or guardians, especially on environmental issues, by researching the elements in curricula that encourage students to talk with them (usually at mealtimes) about what they have been doing in school environmental education courses. Among the identified features that can easily be incorporated into recommendations for course design for course design are: novel learning experiences, fieldwork, research-oriented homework assignments, discussion of easily implemented pro-environmental behaviours (walking to school, taking shorter showers, turning off unneeded lights), student presentations at parents' evenings or public meetings, publicizing the programme in the local newspaper, conducting surveys and interviews in the community, and inviting local people to be guest speakers.

It is also worth noting that effective sociopolitical action is more likely when there is a mutually supportive relationship between school and surrounding community. Traditional barriers between school and community need to be dissolved or rendered permeable, with community members present and active in the school, and students and teachers active and involved in the community. The difficulty of building such an atmosphere of interest, trust and shared responsibility and commitment should not be underestimated. It requires strenuous effort on the part of teachers and students. As part of those efforts, we should be encouraging students' familiarity with social media such as Facebook, Instagram, and Twitter to establish networks, express concerns, share thoughts and spread messages about the need for action. Social media enable forms of participation that were not previously possible and can engage significant 
numbers of people who would otherwise be uninvolved. They have the potential to facilitate the building of a more inclusive, participatory, socially just and politically engaged community. Remtulla (2008) identifies three categories of online political activity: (i) awareness and advocacy usage sees the Internet and other forms of ICT as a means of accessing independent and alternative sources of information that may be ignored or suppressed by mainstream media - for example, the Independent Media Center (www. indymedia.org), Wikinews (en.wikinews.org) and Democracy Now (www.democracynow.org); (ii) community-oriented sites seek to spread awareness, share experiences and ideas and build networks within communities; and (iii) action groups endeavour to raise public support for actions related to specific issues (local, regional, national and international). We need to be aware, however, that social inequities and differential access to technological resources can restrict opportunities for those who are already marginalized, unheard or disregarded. They can be further disadvantaged, silenced or excluded from participation in addressing the very problems that most affect them. Massive efforts are needed to ensure that online spaces and the communities that use them are open to everyone.

Students should be encouraged and enabled to use aspects of youth culture to spread a youth-oriented message concerning civic and environmental responsibility. Music can be important in identity construction and reinforcement, helping students gain a better understanding of their own experiences and the experiences of others, raising political awareness and building the solidarity and sense of community that can lead to activism. For many urban youth in the USA, the rap music of hip-hop culture can be a particularly powerful vehicle, enabling them to put their feelings, emotions, needs, aspirations, hopes, joys, fears, disappointments and anger into a form that is respectful of their immediate cultural experiences and will be readily understood by their peers. For example, Ginwright and Cammarota (2007) describe how youth in Oakland (California) organized what they call "guerilla hip-hop"-impromptu mobile concerts with music, rapping, distribution of leaflets and other forms of political education in local parks, shopping malls, street corners and other places where young people hang out.

\section{Being Prepared}

There are many reasons why the translation of this kind of curriculum rhetoric into practical action in real classrooms will be extraordinarily complex and difficult. Such a radical change in the nature of the school curriculum puts a whole raft of new demands on teachers; it challenges many of the assumptions on which schooling is traditionally based; and it is predicated on a commitment to bringing about extensive and wideranging social change at local, regional, national and international levels. Regarding point 1 , there is no doubt that the sheer complexity of the teacher's role in SSI-oriented teaching can be very daunting in prospect: organizer, facilitator, consultant, friendly critic, general arbiter on all manner of disputes and disagreements, examiner, and so on.

All I can say is that it gets easier with practice. Teachers learn best by critical reflection on the circumstances in which they may have "got it wrong" and by striving to work out how they might "do it better" next time, but they also need access to much more research into the kind of problems they are likely to face and the kind of strategies that may help to overcome them. Because this much more radical and critical stance towards science, scientists, and scientific practice is in direct conflict with the traditional school model of science and the image that universities and the science professions have tended to promote, there may be strenuous opposition from scientists and from universities. There are likely to be arguments that an SSI-oriented approach takes too much time and diverts attention away from content aspects of the curriculum, thus "diluting the science curriculum", "reducing science to the level of social science" and "alienating those with a passion for science".

There may also be assertions that the social, economic, historical, political and moral-ethical dimensions of SSI are likely to be poorly addressed because science teachers lack expertise in these areas, and this may lead to lower levels of job satisfaction for science teachers, loss of experienced teachers from the profession 
and a decline in recruitment. There may be opposition from parents, some of whom may regard it as a "soft option" to "proper science" (i.e., abstract, theoretical science assessed by conventional means). There may even be resistance from students, especially the more academically successful ones. They, too, have expectations of science lessons and a vested interest in maintaining classroom practices that have served them well in the past.

A substantial number of science teachers, as well as students, parents, scientists, employers, politicians and others, are likely to hold the view that social, political, economic and moral-ethical issues have no place in the science curriculum (or in any school-based education for that matter) and that sociopolitical action has no place in school. Some will believe that students are not mature enough to cope with SSI or sufficiently interested in addressing them, though my own research extending over many years indicates that these are exactly the things that students do wish to address through the science curriculum. Sadly, there are many in society who would not welcome an articulate, well-informed, critical and active citizenry that is willing, able and determined to challenge and change the status quo. Navigating these multiple resistances to change will require considerable courage and determination and high levels of support and encouragement.

Even teachers who express an interest in teaching about SSI cite lack of time to plan lessons and prepare materials capable of integrating coverage of content with social concerns, economic considerations and moral-ethical dilemmas as a major constraint on their practice. Others cite difficulties associated with design of assessment and evaluation strategies. Conventional assessment methods do not cope well when there is no clearly defined outcome, no certain and unambiguous solution; when the curriculum is extended to include sociopolitical action, evaluation is as much about what the community learns from the activity, or how it is changed by it, as it is about what the students learn.

Clearly, much work will be needed to develop appropriate assessment and evaluation strategies if an issues-based curriculum is to become a reality. Some teachers are concerned that a shift from the supposed "certainties of science" to the uncertainties of SSI-oriented teaching will constitute a threat to their classroom authority and to their role as "gatekeepers of scientific knowledge". Some claim that they lack resources for addressing SSI. This is patently untrue. Newspapers, television reports and Internet websites abound with suitable material. What these teachers are really claiming is that they do not have access to carefully constructed instructional materials that meet the specifications of the official curriculum. Given the track record of such materials in seeking to promote particular political and economic ideologies or inculcate attitudes and codes of good behaviour derived from particular religious beliefs (Marsden, 2001), it is perhaps no bad thing that teachers lack ready-made "official" resources.

As Cross and Price (1996) point out, there is a danger that large corporations and government agencies will respond to teachers' concerns about lack of materials by producing glossy and user-friendly materials that use sophisticated communications techniques to promote a particular position or point of view that is difficult to counter with the relatively unsophisticated curriculum materials generated by teachers, citing the Australian mining industry's advocacy of uranium mining as a case in point.

It is inevitable that some teachers will lack confidence and expertise in handling unstructured, openended discussions, and it is unsurprising that teachers unfamiliar with such an approach commonly express a concern, bordering on anxiety, that they will be accused of bias and that they may possibly lay themselves open to charges of indoctrination. I would make two points in response. First, adoption of the critical approach by Ratcliffe and Grace (2003) as the "stated commitment" approach constitutes a legitimate defence against such charges. Second, the views of students often indicate the exact opposite, with many of the students with whom I have worked expressing the view that SSI-oriented teaching "opened my eyes to other perspectives", "helped me to sort out my own views" and "enabled me to think more clearly and more carefully" about such matters. An interesting study by Pedretti (2003) found that 25 newly qualified teachers who had expressed positive attitudes towards a science, technology, society and environment or SSI orientation put very little of their professed enthusiasm and commitment into practice during their first year of teaching. The list of barriers they identified constitutes a succinct summary of the points raised here: apprehension about dealing with values-laden issues and addressing moral-ethical dilemmas; concern that 
students may not be cognitively and emotionally ready to engage in the discussion of SSI in any meaningful way; insufficient time to develop appropriate teaching and learning experiences; a general perception that the complexity and uncertainty of the decision-making phase associated with SSI-oriented teaching is difficult to translate into effective curriculum experiences; and little or no confidence in their ability to assess learning in this area. Although not mentioned by any of Pedretti's teachers, several of the science teachers with whom I have worked in Toronto and Hong Kong expressed a concern that some SSI are so highly charged emotionally and so potentially divisive that they are unsuitable for productive classroom discussion. My own view is that the emotions generated by SSI can be the most motivating aspect of this kind of curriculum and one of the major reasons why we should be using SSI in class.

One major danger is that actions may reflect the teacher's agenda rather than the interests and concerns of the students, who merely "go through the motions" of engaging in action without any real commitment or sense of empowerment, simply to satisfy course requirements or meet the expectations of the teacher. At the extreme, teachers may be led to compile a list of approved, scripted and politically safe actions in which to involve successive groups of students without ever engaging them in the critical debate that should precede and determine action. Students may be directed towards uncontroversial issues, guided away from conflict, dissuaded from political debate and censored when their proposals seem likely to challenge school practices, local government policies or the interests of local businesses.

Simovska (2008) distinguishes between token participation and genuine participation in terms of "focus" (specified content versus knowledge building through critique and reflection), "outcomes" (acceptance of a particular set of beliefs, values and behaviours versus student autonomy, critical consciousness and ability to address novel and complex issues) and "target of change" (individuals and their specific lifestyle versus individuals in context, taking account of inter-personal relations, sociocultural factors, moral-ethical dimensions and existing organizational structures). The same concerns run through Roth's (2009) urging of teachers not to subordinate experience of activism to the more general aims of schooling and through Sammel and Zandvliet's (2003) note that most approaches to SSI in school are conducted within teachers' perceptions of politically acceptable limits.

It is imperative that teachers find the courage, enlist the support of others and mobilize the resources to be much more challenging, critical and politicized in their approach. Avoiding controversial issues, especially those with very significant political dimensions, is regarded by many teachers as taking a neutral view. In reality, it is not neutral. Because it fails to confront and challenge the underlying sociopolitical causes of environmental problems, for example, it implicitly supports current social practices, current institutions and current values. There is no such thing as political non-involvement. Non-involvement is, in itself, a form of involvement by default and constitutes implicit support for the dominant ideology. Avoiding political matters is, in effect, leaving it for others to decide.

My final point is that the kind of radical curriculum change advocated in this article will only occur when sufficient teachers, teacher educators, curriculum developers and curriculum policymakers are convinced of the importance, desirability and feasibility of addressing SSI in the science classroom and encouraging sociopolitical action, and when there is a commitment to teach and confidence in doing so through awareness of appropriate pedagogical strategies, capacity to organize the required classroom environment and access to suitable resources. We need a critical mass of teachers and teacher educators, and we need to put pressure on policymakers and administrators.

The real breakthrough comes when individual teachers are able to find and work with like-minded colleagues to form influential groups that can begin to inspire key decision-making bodies. This implies that teachers and teacher educators need to be braver than they have been in recent years, and they need to acquire a measure of political literacy regarding the ways in which educational policy is formulated and implemented. Perhaps teachers and teacher educators need to develop the educational equivalent of the public forums (consensus panels, citizen juries, focus groups and the like) that have been used by scientists, governments and NGOs to directly engage the public. 
Finally, teachers need access to case studies of successful SSI-oriented innovations. They will find the necessary inspiration and encouragement in accounts of teachers engaged in similar efforts to overthrow the stultifying shackles of convention. For most people, there is often much greater value (in terms of practical advice and inspiration) in listening to and/or reading the stories of those who have been intimately involved in such projects than in reading detailed prescriptions or generic rules for curriculum implementation. Teachers do not need a set of rules about "what to do"; they need rich, complex, context-specific stories about what was done, why it was done and how successful or unsuccessful it turned out to be.

As noted earlier, addressing controversial SSI in class may provoke opposition from other teachers, school administrators, scientists, universities, parents and members of the local community. Engaging students in sociopolitical action may provoke even more opposition. Although recycling, cleaning up the beach, building nesting boxes or working in the local food bank or shelter for the homeless and other direct actions may be considered safe, benign and non-controversial, challenging local councils, staging demonstrations, conducting vigils and organizing boycotts may raise parental anxiety levels, offend the local community and lead to sustained opposition. Teachers need to be prepared for backlash and they need courage to fly in the face of this opposition. Many will perceive the capacity for effecting social change located in a body of students who are scientifically literate, environmentally aware, socially critical and politically literate as a threat rather than a boon, as a threat to the established order of power and control. Indeed, the very success of the education advocated in these proposals is what is likely to draw the most opposition, so that engagement of students in potentially successful political action may be vigorously resisted.

As noted in Hodson (2010), those teachers who promote involvement and develop action skills are riding a tiger, but it is a tiger that may well have to be ridden if we really mean what we say about education for civic participation. I do not seek to minimize the difficulties that teachers face in implementing an actionoriented curriculum or the courage they will need to fly in the face of potentially very strong opposition. All I can do is urge them (and their students) to be critical, reflective, robust in argument and sensitive to diverse values and beliefs, but above all, to have the courage and strength of will to do what they believe is right and good and just. As Alberto Rodriguez (2001) puts it: we need "to muster the courage to manage the resistance and the risks associated with helping implement our proposed changes... we must have the courage to expand our gaze... and rise to the challenge of becoming cultural warriors for social change" (p. 290).

Finally, in the words of Tom Lehrer (1953), I say to teachers: "Don't be nervous, don't be flustered, don't be scared. Be prepared" (track A3). Don't be nervous about the curriculum implications of adopting an SSIoriented approach (the need for context-specific knowledge, NOS understanding, media literacy, moralethical understanding, and the like); don't be flustered by having to deal with controversy and the cut and thrust of debate that inevitably occurs in small group discussions; don't be scared about the prospect of stepping into the unknown. Above all, be prepared. Be prepared for potential opposition; be prepared in the sense of accumulating appropriate curriculum resources; be prepared in the sense of being committed to the pursuit of an education that promises to make the world better, safer, kinder and more socially just.

\section{Compliance with Ethical Standards}

Conflict of Interest The author states that there is no conflict of interest.

Open Access This article is licensed under a Creative Commons Attribution 4.0 International License, which permits use, sharing, adaptation, distribution and reproduction in any medium or format, as long as you give appropriate credit to the original author(s) and the source, provide a link to the Creative Commons licence, and indicate if changes were made. The images or other third party material in this article are included in the article's Creative Commons licence, unless indicated otherwise in a credit line to the material. If material is not included in the article's Creative Commons licence and your intended use is not permitted by statutory regulation or exceeds the permitted use, you will need to obtain permission directly from the copyright holder. To view a copy of this licence, visit http://creativecommons.org/licenses/by/4.0/. 


\section{References}

Abd-El-Khalick, F. (2012). Examining the sources for our understandings about science: Enduring conflations and critical issues in research on nature of science in science education. International Journal of Science Education, 34(3), 353-374.

Agyeman J. \& Carmin J. 2011. Introduction: Environmental injustice beyond borders. In J. Carmin \& J. Agyeman (Eds.). Environmental Inequalities beyond Borders: Local Perspectives on Gglobal Injustices (pp. I-1 5). Cambridge, MA: MIT Press.

Angell, M. (2004). The Truth about the Drug Companies: How they Deceive us and What to do about it. New York: Random House.

Ballantyne, R., Connell, S. \& Fien, J. (1998). Students as catalysts of environmental change: A framework for researching intergenerational influence through environmental education. Environmental Education Research, 4(3), $285-298$.

Ballantyne, R., Fien, J. \& Packer, J. (2001a). Programme effectiveness in facilitating intergenerational influence in environmental education: Lessons from the field. Journal of Environmental Education, 32(4), 8-15.

Ballantyne, R., Fien, J. \& Packer, J. (2001b). School environmental education program impacts upon family learning: A case study analysis. Environmental Education Research, 7(1), 23-37.

Bingle, W.H. \& Gaskell, P.J. (1994). Scientific literacy for decision making and the social construction of scientific knowledge. Science Education, 78(2), 185-01.

Bisschop. L. (2014). How e-waste challenges environmental governance. International Journal for Crime, Justice and Social Democracy, 3(2), 81-95.

BonJour L. \& Baker A. (Eds.)(2007). Philosophical Problems: An Annotated Anthology. New York: PearsonLongman.

Bullard, R.D. \& Johnson, G.S. (2000). Environmental justice: Grassroots activism and its impact on public policy decision making. Journal of Social Issues, 56(3), 555-578.

Chawla, L. \& Flanders Cushing, D. (2007). Education for strategic environmental behaviour. Environmental Education Research, 13(4), 437-452.

Chopra, S. (2009). Globalisation, food security, public health \& prosperity focus on India. Journal of Activist Science \& Technology Education, 1(1), 61-64.

Cross, R.T. \& Price, R.F.(1996). Science teachers' social conscience and the role of controversial issues in the teaching of science. Journal of Research in Science Teaching, 33, 319-333.

Elam, M. \& Bertillson, M. (2003) Consuming, engaging and confronting science: The emerging dimensions of scientific citizenship. European Journal of Social Theory, 6(2), 233-251.

Fletcher, A.C., Elder, G. \& Mekos, D. (2000). Parental influences on adolescent involvement in community activities. Journal of Research on Adolescence, 10(1), 29-48.

France. B., Mora. H. A. \& Bav, J. B. (2012). Changing perspectives: Exploring a pedagogy to examine other perspectives about stem cell research. International Journal of Science Education, 34(5), 803-824.

Fullick, P. \& Ratcliffe, M. (Eds.) (1996). Teaching ethical aspects of science. Totton: Bassett Press.

Ginwright, S. \& Cammarota, J. (2007). Youth activism in the urban community: Learning critical civic praxis within community organizations. International Journal of Qualitative Studies in Education, 20(6), 693-710.

Girod, M., Rau, C. \& Schepige, A. (2003). Appreciating the beauty of science ideas: Teaching for aesthetic understanding. Science Education, 87(4), 574-587.

González-Gaudiano, E. \& Meira-Cartea, P. (2010). Climate change education and communication: A critical perspective on obstacles and resistances. In F. Kagawa \& D. Selby (Eds.), Education and climate change: Living and learning in interesting times (pp. 13-34). London: Routledge.

Greenpeace. (2008). Poisoning the Poor: Electronic waste in Ghana. Amsterdam: Greenpeace International.

Halverson, K.L., Siegel, M.A. \& Freyermuth, S.R. (2009). Lenses for framing decisions: Undergraduates' decision making about stem cell research. International Journal of Science Education, 31(9), 1249-1268.

Hodson, D. (2010). Science education as a call to action. Canadian Journal of Science, Mathematics and Technology Education, 10(3), 197-206.

Hodson, D. (2011). Looking to the Future: Building a Curriculum for Social Activism. Rotterdam: Sense Publishers.

Hursthouse, R. (1999). On Virtue Ethics. Oxford: Oxford University Press.

Jones, A., McKim, A. \& Reiss, M. (Eds.) (2010), Ethics in the Science and Technology Classroom: A New Approach to Teaching and Learning. Rotterdam: Sense Publishers.

Kelly, T. (1986). Discussing controversial issues: Four perspectives on the teacher's role. Theory and Research in Social Education, 14, 113-138.

Knight. A.J. (2009). Perceptions. knowledge and ethical concerns with GM foods and the GM process. Public Understanding of Science, 18, 177-188.

Kolstø, S.D. (2001). Scientific literacy for citizenship: Tools for dealing with the science dimension of controversial socioscientific issues. Science Education, 85(3), 291-310.

Kyle, W.C. (1996). Editorial: The importance of investing in human resources. Journal of Research in Science Teaching, 33, 1-4.

Latour, B. (1987). Science in Action: How to Follow Scientists and Engineers through Society. Cambridge, MA: Harvard University Press. 
Lederman, N.G., Abd-El-Khalick, F., Bell, R.L. \& Schwartz, R. S. (2002). Views of nature of science questionnaire: Toward valid and meaningful assessment of learners' conceptions of nature of science. Journal of Research in Science Teaching, $39(6), 497-521$.

Lemke, J.L. (2001). Articulating communities: Sociocultural perspectives on science education. Journal of Research in Science Teaching, 38(3), 296-316.

Lester, B.T., Ma, L., Lee, O. \& Lambert, J. (2006). Social activism in elementary science education: A science, technology, and society approach to teach global warming. International Journal of Science Education, 28(4), 315-339.

Lindemann-Matthies, P. (2005). 'Loveable' mammals and 'lifeless' plants: How children's interest in common local organisms can be enhanced through observation of nature. International Journal of Science Education, 27(6), 655-677.

Liston, D. (2004). The allure of beauty and the pain of injustice in learning and teaching. In D. Liston \& J. Garrison (Eds.), Teaching, Learning and Loving: Reclaiming Passion in Educational Practice (pp. 101-116). New York: RoutledgeFalmer.

Marsden, B. (2001). Citizenship education: Permeation or pervasion? Some historical pointers. In D. Lambert \& P. Machon (Eds.), Citizenship through secondary geography (pp. 1-30). London, England: RoutledgeFalmer.

Matthews, B. (2005). Emotional development, science and co-education. In S. Alsop (Ed.), Beyond Cartesian Dualism: Encountering Affect in the Teaching and Learning of Science (pp. 173-186). Dordrecht: Springer.

Maxwell, N. (1984). From Knowledge to Wisdom. Oxford: Basil Blackwell.

Maxwell, N. (1992). What kind of inquiry can best help us create a good world? Science, Technology \& Human Values, 17(2), 205-227.

McClaren, M. \& Hammond, B. (2005). Integrating education and action in environmental education. In E.A. Johnson \& M.J. Mappin (Eds.), Environmental Education and Advocacy: Changing Perspectives of Ecology and Education (pp. 267-291). Cambridge: Cambridge University Press.

Minaya, Z. \& Downing, J. (nd). Matamoras: Toxic Legacy. Available at: https://journalism.berkeley.edu/projects/border/matamoras. html. Accessed 19 Nov 2020.

Pancer, S.M. \& Pratt, M.W. (1999). Social and family determinants of community service involvement in Canadian youth. In M. Yates \& J. Youniss (Eds.), Roots of Civic Identity (pp. 32-55). Cambridge: Cambridge University Press.

Pedretti, E. (1997). Septic tank crisis: A case study of science, technology and society education in an elementary school. International Journal of Science Education, 19(10), 1211-1230.

Pedretti, E. (2003). Teaching science, technology, society and environment (STSE) education: Preservice teachers' philsophical and pedagogical landscapes. In D. L. Zeidler (Ed.), The Role of Moral Reasoning on Socioscientific Issues and Discourse in Science Education (pp. 219-239). Dordrecht, The Netherlands: Kluwer.

Ratcliffe, M. \& Grace, M. (2003). Science Education for Citizenship: Teaching Socio-scientific Issues. Maidenhead: Open University Press.

Remtulla, K.A. (2008). Democracy or digital divide? The pedagogical paradoxes of online activism. In D.E. Lind \& P.R Carr (Eds.), Doing Democracy: Striving for Political Literacy and Social Justice (pp. 267-280). New York: Peter Lang.

Rodriguez, A.J. (2001). Courage and the researcher's gaze: (Re)defining our roles as cultural warriors for social change. Journal of Science Teacher Education, 12(3), 277-294.

Roth, W-M. (2009). Activism or science/technology education as a by-product of capacity building. Journal of Activist Science \& Technology Education, 1(1), 16-31.

Sammel, A. \& Zandvliet, D. (2003). Science reform or science conform: Problematic epistemological assumptions with/in Canadian science reform efforts. Canadian Journal of Science, Mathematics and Technology Education, 3(4), 513-520.

Schusler, T.M., Krasny, M.E., Peters, S.J. \& Decker, D.J. (2009). Developing citizens and communities through youth environmental action. Environmental Education Research, 15(1), 111-127.

Shen, B.S.P. (1975). Scientific literacy and the public understanding of science. In S.B. Day (Ed.), The Communication of Scientific Information (pp.44-52). Basel: Karger.

Simmons, M.L. \& Zeidler, D. (2003). Beliefs in the nature of science and responses to socioscientific issue. In D.L. Zeidler (Ed.), The Role of Moral Reasoning on Socioscientific Issues and Discourse in Science Education (pp. 81-94). Dordrecht: Kluwer.

Simovska, V. (2008). Learning in and as participation: A case stuidy from health-promoting schools. In A. Reid, B.B. Jensen, J. Nikel \& V. Simovsla (Eds.), Participation and Learning: Perspectives on Education and the Environment, Health and Sustainability (pp. 61-80). New York: Springer.

Singer. P. (Ed.) 1991, Companion to Ethics. Oxford: Basil Blackwell.

Sperling, E. (2009). 'More than particle theory': Action-oriented citizenship through science education in a school setting. Journal of Activist Science \& Technology Education, 1(2), 12-30.

Stelfox, H.T., Chua, G., O'Rourke, G.K. \& Detsky, A.S. (1998). Conflict of interest in the debate over calcium channel antagonists. New England Journal of Medicine, 338(1), 101-106.

Tom Lehrer. (1953). Be Prepared. Songs by Tom Lehrer, track 2.

Young, R.M. (1987). Racist society, racist science. In D. Gill \& L. Levidow (Eds.), Anti-racist Science Teaching (pp. 16-42). London: Free Association Books.

Zeidler, D.L. \& Sadler, T.D. (2008a). The role of moral reasoning in argumentation: Conscience, character and care. In S. Erduran \& M.P. Jiménez-Aleixandre (Eds.), Argumentation in Science Education: Perspectives from Classroom-based Research (pp. 201-216). Dordrecht: Springer. 
Zeidler, D.L. \& Sadler, T.D. (2008b). Social and ethical issues in science education: A prelude to action. Science \& Education, 17(8\&9), 799-803.

Zeidler, D.L., Walker, K.A., Ackett, W.A. \& Simmons, M.L. (2002). Tangled up in views: Beliefs in the nature of science and responses to socioscientific dilemmas. Science Education, 86(3), 343-367.

Zeidler, D. L., Sadler, T. D., Simmons, M. L., \& Howes, E. V. (2005). Beyond STS: A research-based framework for socioscientific issues education. Science Education, 89(3), 357-377.

Zeidler, D.L., Sadler, T.D., Applebaum, S. \& Callahan, B.E. (2009). Advancing reflective judgment through socioscientific issues. Journal of Research in Science Teaching, 46(1), 74-101.

Publisher's Note Springer Nature remains neutral with regard to jurisdictional claims in published maps and institutional affiliations. 